Journal Of Sea Research

September 2015, Volume 103 Pages 138-146

http://dx.doi.org/10.1016/i.seares.2015.06.011

http://archimer.ifremer.fr/doc/00272/38314/

(c) 2015 Elsevier B.V. All rights reserved.

\title{
Trophic niche overlap of sprat and commercial small pelagic teleosts in the Gulf of Lions (NW Mediterranean Sea)
}

\author{
Le Bourg B. ${ }^{1}$, Banaru Daniela ${ }^{1,{ }^{*}}$, Saraux Claire ${ }^{2}$, Nowaczyk A. ${ }^{1,3}$, Le Luherne E. ${ }^{1,4}$, \\ Jadaud Angelique ${ }^{2}$, Bigot Jean-Louis ${ }^{2}$, Richard P. ${ }^{5}$
}

${ }^{1}$ Aix Marseille Univ, CNRS INSU, IRD, MIO, F-13288 Marseille, France.

2 IFREMER, CRH, UMR MARBEC IRD IFREMER UM CNRS, F-34203 Sete, France.

${ }^{3}$ Univ Bordeaux, UMR CNRS EPOC OASU 5805, F-33120 Arcachon, France.

${ }^{4}$ Agrocampus Ouest, ESE Ecol \& Sante Ecosyst UMR985, F-35042 Rennes, France.

${ }^{5}$ Univ La Rochelle, UMR CNRS LIENSs 7266, F-17000 La Rochelle, France.

* Corresponding author: Daniela Banaru, email address : daniela.banaru@univ-amu.fr ;

lebourg.bap@orange.fr ; Claire.Saraux@ifremer.fr ; a.nowaczyk@epoc.u-bordeaux1.fr ; emilie.leluherne@agrocampus-ouest.fr ; Angelique.Jadaud@ifremer.fr ; Jean-Louis.Bigot@ifremer.fr ; pierre.richard01@univ-Ir.fr

\begin{abstract}
:
Increasing abundance of non-commercial sprats and decreasing biomass and landings of commercial anchovies and sardines justify the need to study the feeding ecology and trophic niche overlap of these planktivorous species in the Gulf of Lions. Their diet has been investigated on the basis of stomach content and stable isotope analyses in 2011 and 2012 according to different depths and regions in the study area. The main prey were Corycaeidae copepods, Clauso/Paracalanus, Euterpina acutifrons and Microsetella, for sprats and small copepods, such as Microsetella, Oncaea and Corycaeidae, for anchovies and sardines. This is the first time that the diet of sprats is described in the Gulf of Lions. Sprats fed on a larger size spectrum of prey and seem to be more generalist feeders compared to anchovies and sardines. Ontogenetic changes as well as spatial and temporal variations of the diet occurred in the three species. Stable isotope analysis revealed mobility of sardines and sprats among feeding areas while anchovies exhibited preferred feeding areas. Sprats showed a higher relative condition assessed by $\mathrm{C} / \mathrm{N}$ ratios than sardines and anchovies. Our results showed an overlap of the trophic niches for the three species, indicating a potential trophic competition in the Gulf of Lions.
\end{abstract}




\section{Highlights}

- Sprats' diet was described for the first time in the NW Mediterranean Sea. There was a high trophic overlap for sardines, anchovies and sprats. Spatio-temporal and ontogenetic variations of their diet were described. Sprats were more generalist than sardines and anchovies and fed on larger prey. Diet particularities may explain the better relative condition of sprats.

Keywords : Anchovies, Sardines, Sprats, North-western Mediterranean sea, Stomach contents, Stable isotopes

\section{Introduction}

Small pelagic teleosts are key species in ecological systems as they ensure the transfer of organic matter from zooplankton to higher trophic levels (Banaru et al., 2013). They may exert different types of control in marine systems such as bottom-up (Cury et al., 2011), top-down (Köster and Möllmann, 2000; Verheye and Richardson, 1998) or wasp-waist control (Cury et al., 2000).

Traditionally, anchovies (Engraulis encrasicolus; Linnaeus, 1758) and sardines (Sardina pilchardus; Walbaum, 1792) were the two main pelagic teleosts in the Gulf of Lions (North-West Mediterranean Sea) in terms of biomass and represent target and commercial species for the fishing industry (Banaru et al., 2013). However, anchovy and sardine landings have declined since 2005 and fishing activity has been reduced to an exploratory activity in 2010. Anchovies and sardines are still abundant but their biomasses and size have decreased, which lowers their commercial value. Furthermore, there has been an unusual increase of non-commercial sprat (Sprattus sprattus; Linnaeus, 1758) abundance since 2008 (Van Beveren et al., 2014). A recent decline was reported in body condition and growth of anchovies and sardines (Van Beveren et al., 2014) which might be linked to changes in their diet compared to past studies (Costalago and Palomera, 2014; Plounevez and Champalbert, 2000) and/or to trophic interactions with sprats. Indeed, the abundance of prey seems to be one of the main environmental drivers of body condition in these species (Brosset et al., 
in press). The three species are zooplanktivorous and may be competitors for food in the study area.

59 Moreover, there is significant overlap in their spatial distribution (Saraux et al., 2014) but no data

60 are available concerning their trophic interactions in this area. No qualitative or quantitative data on

61 the zooplankton community are available to show eventual changes in the availability of the

62 resources during the last period. Consequently, studies on their feeding behaviour and interactions

63 are necessary to understand the origin of the recent shifts in the pelagic ecosystem of the Gulf of 64 Lions.

65 Stomach content analysis is a well-known method to study the trophic ecology of teleosts and 66 provides a qualitative and quantitative snapshot of the diet (Hyslop, 1980). Ratios of nitrogen and carbon isotopes $\left({ }^{14} \mathrm{~N}:{ }^{15} \mathrm{~N}, \delta^{15} \mathrm{~N} ;{ }^{12} \mathrm{C}:{ }^{13} \mathrm{C}, \delta^{13} \mathrm{C}\right)$ are used to determine feeding areas and primary sources of carbon in food-web (Hobson, 1999; Michener and Kaufman, 2007). Stable isotope analyses allow longer-term study of the diet of organisms and identification of changes in feeding sources and areas. Carbon/nitrogen $(\mathrm{C} / \mathrm{N})$ ratios measured with stable isotope ratios are a proxy of the lipid content of organisms (Dempson et al., 2010; Logan et al., 2008; Post et al., 2007; Sweeting et al., 2006) and thus can be used as indicators of the relative condition.

Some studies on the trophic ecology of small pelagic teleosts of the European coasts have been previously conducted using stomach content analyses (e.g. Costalago and Palomera, 2014; Costalago et al., 2014; Garrido et al., 2008; Plounevez and Champalbert, 2000; Tičina et al., 2000) and stable isotopes (e.g. Bode et al., 2004; Chouvelon et al., 2014; Costalago et al., 2012), but few studies have combined the two approaches (Pasquaud et al., 2008) and none of them in the study area. Moreover, the last diet studies based on stomach content analysis of adult anchovies and sardines in the Gulf of Lions were performed in 1995-1996 by Plounevez and Champalbert (2000), and in 2007 by Costalago and Palomera (2014), when these species had higher condition values

81 (Brosset et al., in press; Van Beveren et al., 2014) and before the fall of their biomass. No data on the trophic ecology of S. sprattus is available for the North-Western Mediterranean Sea. 
84 isotopes to describe the trophic ecology, niche width and diet overlap of anchovies (E. encrasicolus),

85 sardines (S. pilchardus) and sprats (S. sprattus) in the Gulf of Lions to infer the potential

86 interactions between the three species. In addition, this is the first time that spatial variations in the

87 diet of these species related to their stable isotope ratios were described in the North-Western

88 Mediterranean Sea.

2. Material and methods

\subsection{Study area and sampling}

The Gulf of Lions has a wide continental shelf. It is a mesotrophic area influenced by Rhône

93 river inputs and the northern current flowing southwestwards along the continental slope (Espinasse

94 et al., 2014a). Consequently, concentrations of nutrients in water and sediments decrease from east

95 to west and from coast to continental shelf (Cruzado and Velasquez, 1990; Denis and Grenz, 2003;

96 Van Den Broeck and Moutin, 2002). Furthermore, river inputs influence isotopic ratios of

97 particulate organic matter and phytoplankton with higher $\delta^{15} \mathrm{~N}$ and lower $\delta^{13} \mathrm{C}$ in waters influenced

98 by the Rhône plume (Harmelin-Vivien et al., 2008). Espinasse et al. (2014a) divided the gulf into

99 three habitat types: the western part of the coast, most of the eastern area of the gulf influenced by

100 Rhône river (the coast and a part of the continental shelf), and the continental shelf (except in

101 eastern areas where river inputs are high). In the present study, the gulf has been divided into two

102 depth zones (coastal areas and continental shelf) separated by the 50 metres isobath and three

103 regions (west, centre and east) according to the spatial changes of environmental conditions

104 (Espinasse et al., 2014a; Harmelin-Vivien et al., 2008 Fig. 1).

105 Teleosts were sampled in June and July 2011 and 2012 during the IFREMER MEDITS and

106 PELMED campaigns aboard the IFREMER R.V. 'l'Europe'. In addition, small juvenile sardines

107 were sampled in May 2011 by beach seining near the Rhône estuary. Sampled teleosts were

108 immediately frozen to avoid digestion. In the laboratory, the following measurements were taken on

109 each teleost: total length (TL) to the nearest $1 \mathrm{~mm}$ and total body weight (TW). Stomachs were 
111 dorsal muscles of teleosts were sampled and freeze-dried for subsequent stable isotope analyses.

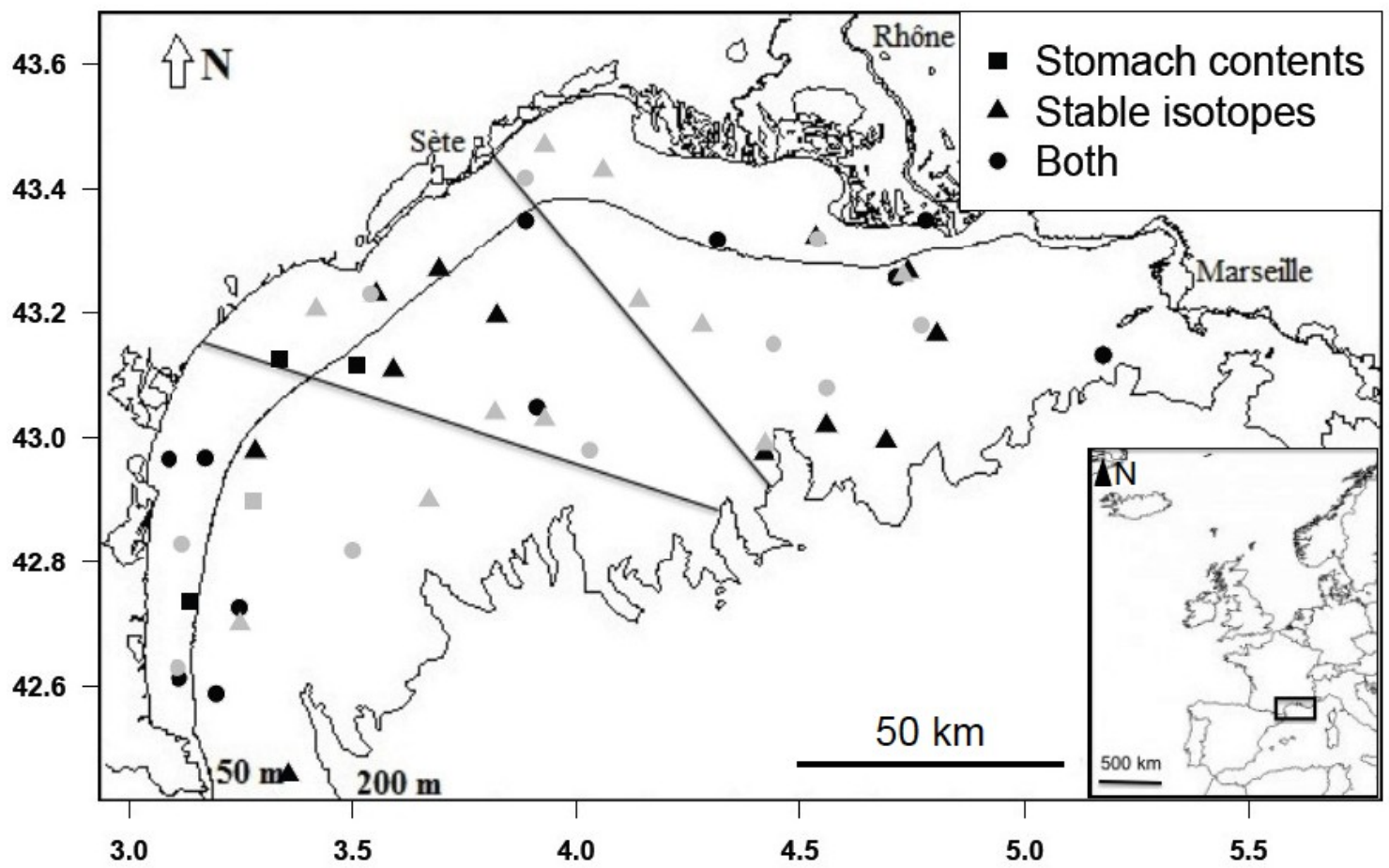

114 Fig. 1. Location of sampling stations in the Gulf of Lions selected for stomach content analysis 115 and/or stable isotope analysis in 2011 (black) and 2012 (grey). The 50 metre isobath separates 116 coastal areas and the continental shelf. The lines separate the regions west, centre and east.

\subsection{Stomach content analysis}

We chose individuals of the different available size classes $(1 \mathrm{~cm}$ interval) for each depth and region. Selected stomach contents (117 anchovies, 145 sardines, 166 sprats) (Fig. 1; Table 1.a) were weighted. In each stomach, ingested organisms were identified to genus level (if possible) and counted. Dry weight (DW) of ingested organisms was obtained from the literature (Table A.1).

123 Food composition was expressed by frequency of occurrence $(\% \mathrm{O}$; percentage of non-empty

124 stomachs containing a given prey item), numerical percentage $(\% \mathrm{~N}$; mean percentage per stomach 125 of the number of a given prey item as a proportion of the total number of all prey in each stomach), 126 weight percentage $(\% \mathrm{~W}$; mean percentage per stomach of the weight of a given prey item as a 
127 proportion of the total weight of all prey in each stomach). The index of relative importance (IRI)

128 (Pinkas et al., 1971) was then calculated according to the formula:

$$
\mathrm{IRI}=\% \mathrm{O} \times(\% \mathrm{~N}+\% \mathrm{~W})
$$

IRI was then transformed in percentage by dividing it by the sum of IRI for each prey item

131 (\%IRI; Cortés, 1997). Niche width $\left(\mathrm{B}_{\mathrm{G}}\right)$ and diet overlap (\%T; Schoener, 1970) were calculated 132 according to formulas:

where $\% \mathrm{IRI}_{\mathrm{xi}}$ and $\% \mathrm{IRI}_{\mathrm{yi}}$ are $\% \mathrm{IRI}$ for the prey item $\mathrm{i}$ in the teleost species $\mathrm{x}$ and $\mathrm{y}$. Overlap is considered as significant if $\% \mathrm{~T}$ exceeds $60 \%$ (Arculeo et al, 1993). \% $\mathrm{T}$ was also calculated using $\% \mathrm{~W}$.

Prey were measured for subsamples of the three studied species ( 82 anchovies, 64 sardines,

58 sprats) for different size classes. Predator/prey size ratios were also estimated for each species.

\subsection{Stable isotope analysis}

For each species, depth and region, stable isotope ratios were studied in muscle samples of

143 fish collected in various sampling stations (104 anchovies, 101 sardines, 116 sprats) (Fig. 1; Table

144 1.b). Selected muscle were freeze-dried and then ground into a fine powder. Subsamples were weighed $(0.4$ to $0.5 \mathrm{mg})$ in $5 \times 8$ tin cups and analysed with a continuous-flow isotope-ratio mass spectrometer (Delta V Advantage, Thermo Scientific) coupled to an elemental analyser (Flash EA 1112, Thermo Scientific). $\delta^{15} \mathrm{~N}$ and $\delta^{13} \mathrm{C}$ were expressed in \%o according to the formula:

$$
\delta \mathrm{X}_{\text {sample }}=\left[\left(\mathrm{R}_{\text {sample }} / \mathrm{R}_{\text {standard }}\right)-1\right] \times 1000
$$

where $\mathrm{X}$ is ${ }^{13} \mathrm{C}$ or ${ }^{15} \mathrm{~N}, \mathrm{R}_{\text {sample }}$ is the isotopic ratio of sample and $\mathrm{R}_{\text {standard }}$ is the isotopic ratio of standards (atmospheric nitrogen for $\delta^{15} \mathrm{~N}$ and Pee Dee Belemnite for $\delta^{13} \mathrm{C}$ ). according to the formula developed by Post et al. (2007): 


$$
\delta^{13} \mathrm{C}_{\text {normalised }}=\delta^{13} \mathrm{C}_{\text {sample }}-3.32+0.99 \times \mathrm{C} / \mathrm{N}
$$

In order to study isotopic niches of the three species, standard ellipses were generated and the

155 Standard Ellipse Areas (SEA) were corrected for sample size $\left(\mathrm{SEA}_{\mathrm{C}}\right.$ ) using the SIAR package

156 (Stable Isotope Analysis in R, Parnell et al., 2010). The overlap between the ellipses was then determined. Isotopic niche of the three species was estimated by determining areas of the ellipses using the bayesian method (SEA $\left.{ }_{B}\right)($ Jackson et al., 2011).

The relative condition factor was estimated using $\mathrm{C} / \mathrm{N}$ ratios related to the lipid content.

\section{Table 1}

162 Number and size range (in brackets, $\mathrm{cm}$ ) of the analysed individuals in the study area for a) stomach

163 content and b) stable isotopes samples.

a)

\begin{tabular}{lcccccc}
\hline \multirow{2}{*}{ Species } & \multicolumn{2}{c}{ West } & \multicolumn{2}{c}{ Centre } & \multicolumn{2}{c}{ East } \\
& Coast & Shelf & Coast & Shelf & Coast & Shelf \\
\hline E. encrasicolus & $26(9.4-12.5)$ & $18(8.5-12.3)$ & $22(8.4-11.6)$ & $7(9.8-12.7)$ & $15(8.5-11.7)$ & $29(9.4-14.0)$ \\
S. pilchardus & $20(10.5-14.2)$ & $16(7.5-14.2)$ & $28(9.3-12.5)$ & 0 & $47(3.9-13.1)$ & $34(10.4-16.5)$ \\
S. sprattus & $56(6.3-10.8)$ & $20(7.4-10.5)$ & $15(7.1-10.0)$ & $10(9.3-10.8)$ & $23(7.3-10.2)$ & $42(7.3-11.2)$ \\
\hline
\end{tabular}

b)

\begin{tabular}{lcccccc}
\hline \multirow{2}{*}{ Species } & \multicolumn{2}{c}{ West } & \multicolumn{2}{c}{ Centre } & \multicolumn{2}{c}{ East } \\
& Coast & Shelf & Coast & Shelf & Coast & Shelf \\
\hline E. encrasicolus & $11(8.0-10.3)$ & $16(8.5-11.6)$ & $9(3.5-10.3)$ & $12(9.5-11.1)$ & $15(8.6-10.3)$ & $41(8.7-14.0)$ \\
S. pilchardus & $16(11.0-13.1)$ & $12(11.2-15.0)$ & $8(9.3-12.5)$ & $8(11.6-14.1)$ & $24(3.8-14.2)$ & $33(9.3-16.5)$ \\
S. sprattus & $11(6.3-10.7)$ & $24(8.0-10.2)$ & $15(7.5-10.3)$ & $12(9.3-10.1)$ & $18(6.3-10.0)$ & $36(8.0-11.0)$ \\
\hline
\end{tabular}

\subsection{Data analyses}

All data analyses were performed with the R statistical software (version 2.15.0).

Classifications (based on Bray-Curtis dissimilarity index) were performed on \%IRI in each

total length class $(1 \mathrm{~cm}$ interval) to study ontogenetic shifts in the diet of each species. The same classifications were also applied on \%IRI in each zone (defined by region, depth and year of sampling) for each species to study spatial and temporal variations in their diet.

Normality of residuals and homoscedasticity were checked by Shapiro tests, Q-Q plots and

173 Levene tests. Ontogenetic changes in the size classes of prey consumed by anchovies, sardines and 
174 sprats were studied with Spearman rank correlation tests (rho) between teleosts total length and

175 individual prey length for each of the three species. Predator/prey size ratios were compared

176 between the three species by Kruskal-Wallis tests $(\mathrm{H})$.

Stable isotope and $\mathrm{C} / \mathrm{N}$ ratios were compared between the three species by Kruskal-Wallis

tests. For each species, Student's t-tests (t), or Wilcoxon tests (W) if data did not fit to a normal

distribution pattern, were performed to compare isotopic and $\mathrm{C} / \mathrm{N}$ ratios between the years 2011 and

2012. Subsequent analyses were performed on separate years or the pooled two years if the year factor was not significant.

Type III analyses of covariances (ANCOVA; F) were performed with the factors length,

region, depth and their interaction on isotopic and $\mathrm{C} / \mathrm{N}$ ratios. The teleosts total length covariate was deleted from the models if its effect on the isotopic and $\mathrm{C} / \mathrm{N}$ ratios was non-significant. Scheffé post-hoc tests were performed when the region significantly influenced isotopic or $\mathrm{C} / \mathrm{N}$ ratios.

\section{Results}

\subsection{Diet composition}

Proportions of empty stomachs were $11.11 \%$ for anchovies, $18.62 \%$ for sardines $30.72 \%$ for

sprats. Fifty-five prey items were identified in the stomachs (anchovies: 43, sardines: 33, sprats:

37). The three species fed mainly on copepods $(\% \mathrm{IRI}=93.91$ for anchovies, 92.08 for sardines and

Anchovies had the lowest niche width $\left(\mathrm{B}_{\mathrm{G}}=15.52\right)$ and their diet was dominated by the

194 copepods Microsetella $(\% \mathrm{IRI}=32.06)$, Oncaea $(\% \mathrm{IRI}=25.25)$ and the Corycaeidae family $(\% \mathrm{IRI}$ $195=16.62)$. Microsetella $(\% \mathrm{IRI}=28.63)$, Oncaea $(\% \mathrm{IRI}=23.70)$ and the Corycaeidae family $(\% \mathrm{IRI}$ $196=20.25)$ also dominated the diet of sardines. Sardines had a higher niche width $\left(\mathrm{B}_{\mathrm{G}}=16.67\right)$ than 197 anchovies. Sprats had a more diversified diet $\left(\mathrm{B}_{\mathrm{G}}=17.87\right)$ dominated by Clauso/Paracalanus $198(\% \mathrm{IRI}=23.41)$, the Corycaeidae family $(\% \mathrm{IRI}=19.04)$, Euterpina acutifrons $(\% \mathrm{IRI}=14.61)$ and 199 Microsetella $(\% \mathrm{IRI}=10.08)$. 


\subsection{Ontogenetic variations in diet}

202 Cluster analyses of teleosts diets (based on \%IRI) by size classes are shown in Fig. 2.

203 Stomach contents show that Oncaea was the main prey for 8-10 $\mathrm{cm}$ long anchovies, which

204 also fed on Microsetella, Corycaeidae copepods and on some unidentified copepods. Anchovies 205 with a 10-12 cm body size consumed mainly Microsetella, but also Corycaeidae copepods and 206 Oncaea. Larger anchovies $(12-13 \mathrm{~cm})$ consumed mainly copepods from the Corycaeidae family $207(\% \mathrm{IRI}=23.05)$, but also large diatoms $(\% \mathrm{IRI}=14.67)$ and the copepod species Centropages 208 typicus $(\% \mathrm{IRI}=12.40)$. In fact, contribution of diatoms and Centropages typicus increased with 209 body length while that of Oncaea decreased.

a)

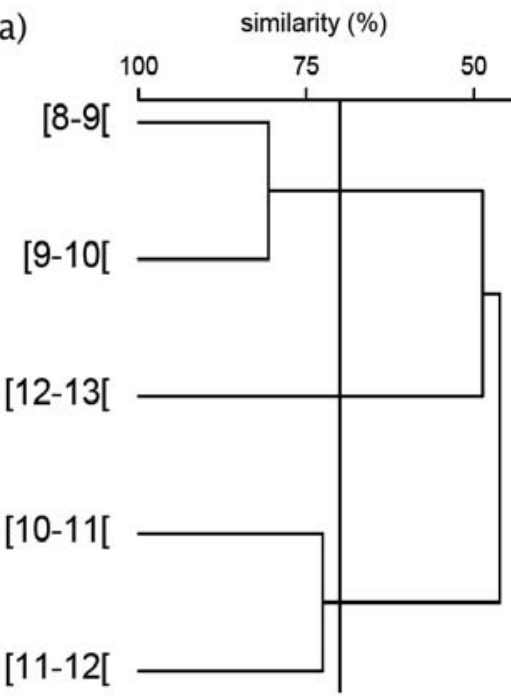

b)

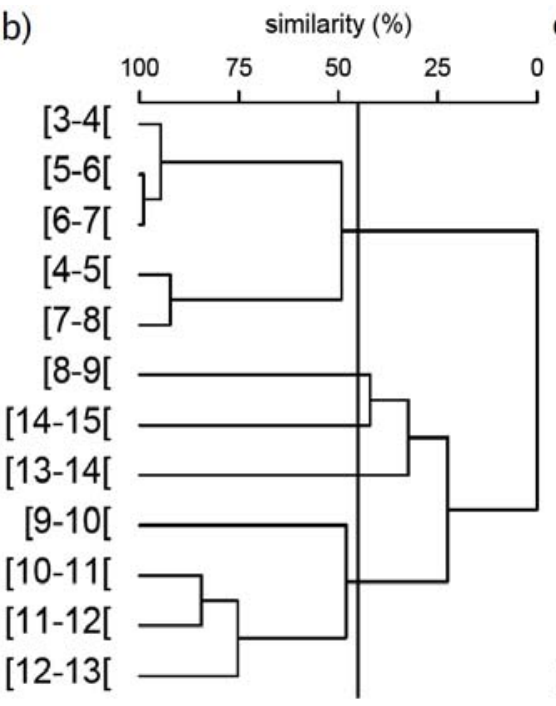

c)

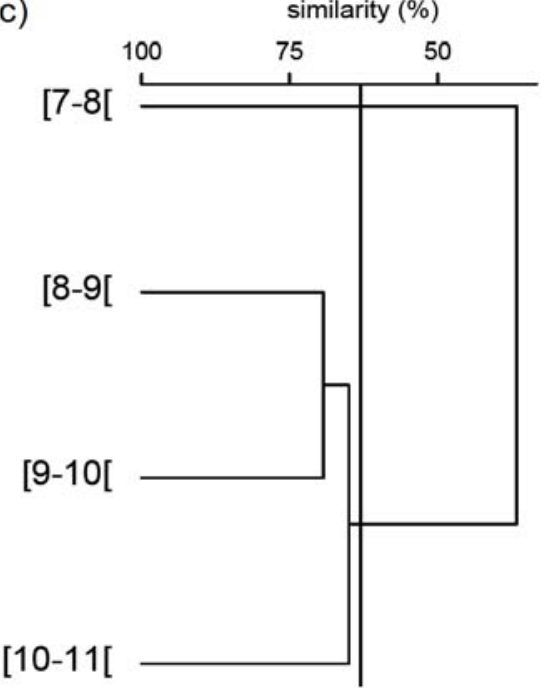

211 Fig. 2. Cluster analyses of diet similarities (based on \%IRI) among size classes (cm) in a)

212 anchovies, b) sardines, c) sprats. The vertical line separates the clusters.

Sardines between 3 and $8 \mathrm{~cm}$ consumed mainly suprabenthic mysids (genus Paramysis).

215 Unidentified copepods were also consumed by 4-5 and 7-8 $\mathrm{cm}$ sardines. Sardines between and 9 and $13 \mathrm{~cm}$ fed on Microsetella and Oncaea. Among those sardines, 9-10 cm individuals fed also on

217 Euterpina acutifrons $(\% \mathrm{IRI}=24.48)$ and bivalve larvae $(\% \mathrm{IRI}=12.26)$ while $10-13 \mathrm{~cm}$ sardines 218 fed on Corycaeidae. The size classes 8-9 cm, 13-14 cm and 14-15 cm had unusual diets. The first 
219 size class fed on Microsetella $(\% \mathrm{IRI}=36.01)$ but had high contribution of Acartia $(\% \mathrm{IRI}=16.40)$

220 and unidentified copepods $(\% \mathrm{IRI}=37.06)$ in its diet. The second size class fed on Corycaeidae

$221(\%$ IRI $=18.85)$ but also on Acartia $(\%$ IRI $=25.46)$, diatoms $(\%$ IRI $=21.47)$ and unidentified

222 copepods $(\% \mathrm{IRI}=12.24)$. The last size class fed on Microsetella $(\% \mathrm{IRI}=50.00)$ but also on

223 diatoms $(\% \mathrm{IRI}=37.09)$.

224 The main prey of small sprats $(7-8 \mathrm{~cm})$ were unidentified copepods $(\% \mathrm{IRI}=48.09)$.

225 Nevertheless, Euterpina acutifrons (\%IRI = 16.13), Oncaea $(\% \mathrm{IRI}=11.82)$ were the most

226 important identified prey items for this body size. Sprats between 8 and $11 \mathrm{~cm}$ had a diet dominated

227 by two prey: Clauso/Paracalanus and the Corycaeidae. Among 8-11 cm sprats, Euterpina

228 acutifrons was also an important prey for sprats between 8 and $10 \mathrm{~cm}$. In fact, the contribution of

229 the Corycaeidae copepods (\%IRI from 4.33 to 33.95 ) increased for larger sprats while that of

230 Oncaea decreased (\%IRI from 11.82 to 3.51$).$

\subsection{Class lengths of the consumed prey}

Anchovies and sardines consumed mainly $0.2-0.6 \mathrm{~mm}$ prey $(62.97 \%$ of all measured prey for anchovies and $52.93 \%$ for sardines $)$, the most consumed size class being the $0.4-0.5 \mathrm{~mm}(20.45 \%$ of all measured prey for anchovies and $15.99 \%$ for sardines). Sprats fed on slightly larger prey as they consumed mainly $0.3-0.7 \mathrm{~mm}$ prey (77.22\% of all measured prey) (Fig. 3). The $0.4-0.5 \mathrm{~mm}$ size class was once again the most consumed one, but this size class was consumed in larger proportions by sprats than by the two other species ( $32.31 \%$ of all measured prey). Furthermore, the $0.5-0.6 \mathrm{~mm}$ size class was also more strongly represented in the diet of sprats (21.94\% of all measured prey) than in that of anchovies $(10.29 \%)$ and sardines $(10.23 \%)$. There was a peak of occurrence in sardines for the 1.0-1.1 mm size class (9.24\% of measured prey) (Fig. 3). Nevertheless, only 11 sardines fed on this size class and the peak resulted from a high number of anchovy eggs (more than 10) in stomachs of 4 sardines in one sampling site. No ontogenetic changes of prey length consumed by anchovies ( $\mathrm{rho}=-0.008, \mathrm{P}=0.738$ ) and sprats ( rho $=0.008, \mathrm{P}=0.791$ ) occurred for 
245 the analysed individuals. In contrast, size classes consumed by sardines slightly decreased when 246 sardines were larger ( $\mathrm{rho}=-0.276, \mathrm{P}<0.001)$. Sprats had the lowest predator/prey size ratios (mean $\pm \mathrm{SD}=176.45 \pm 71.14$ ) followed by 248 anchovies $(236.67 \pm 133.66)$ and sardines $(259.47 \pm 191.69)(\mathrm{H}=135.458, \mathrm{P}<0.001)($ Table 2$)$.

249 Anchovies consumed the largest prey compared to their own size and sardines the smallest. 250 Sardines showed the highest variation between the minimum and the maximum predator/prey size 251 ratios (Table 2).

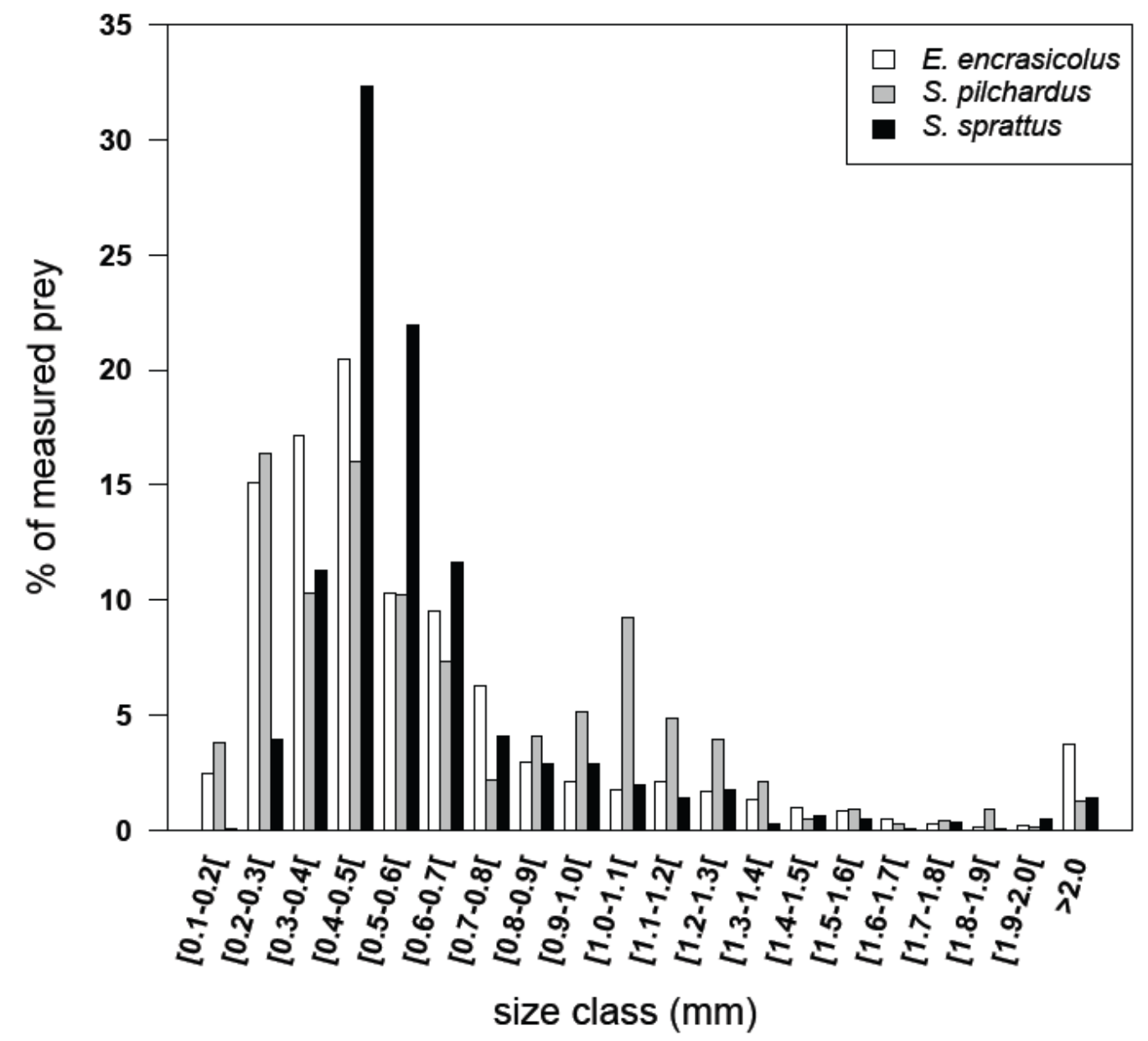

254 Fig. 3. Proportions of the prey size classes in the stomach content of anchovies, sardines and sprats.

Table 2

257 Predator/prey size ratios in anchovies, sardines and sprats $(\mathrm{N}=$ number of individuals, $\mathrm{SD}=$ 258 standard deviation). 


\begin{tabular}{llcccc}
\hline Species & $\begin{array}{l}\text { Predator } \\
\text { lengths }(\mathrm{cm})\end{array}$ & N predators & N prey & Mean \pm SD & Range \\
\hline E. encrasicolus & Total & 82 & 1604 & $236.67 \pm 133.66$ & $7.15-806.22$ \\
& {$[8-10[$} & 27 & 640 & $223.40 \pm 123.79$ & $31.92-700.14$ \\
& {$[10-12[$} & 50 & 865 & $245.50 \pm 137.21$ & $7.15-806.22$ \\
\multirow{5}{*}{ S. pilchardus } & {$[12-13[$} & 5 & 99 & $245.26 \pm 156.24$ & $41.52-773.51$ \\
& Total & 64 & 1007 & $259.47 \pm 191.69$ & $13.00-1621.29$ \\
& {$[3-8[$} & 6 & 33 & $34.23 \pm 26.67$ & $13.00-138.24$ \\
S. sprattus & {$[8-15[$} & 58 & 974 & $267.10 \pm 190.24$ & $33.87-1621.29$ \\
& Total & 58 & 1080 & $176.45 \pm 71.14$ & $21.47-517.05$ \\
& {$[7-8[$} & 6 & 170 & $150.91 \pm 45.41$ & $21.47-359.45$ \\
& {$[8-11[$} & 52 & 910 & $181.22 \pm 74.02$ & $26.88-517.05$ \\
\hline
\end{tabular}

260

\subsection{Spatial and temporal variations in diet}

Dendrograms resulting from hierarchical clustering on teleosts diet similarities (based on \%IRI) among region, depth and year are shown in Fig. 4.

Five clusters appeared for anchovies. The first cluster contained all the coastal stations 265 sampled in 2011 and depicted a diet dominated by Oncaea (\%IRI > 40). The second cluster 266 contained anchovies only sampled in the west, on the shelf in 2011, feeding on Euphausiacean 267 larvae $(\% \mathrm{IRI}=58.48)$, Microsetella $(\% \mathrm{IRI}=12.43)$ and Clauso/Paracalanus $(\% \mathrm{IRI}=11.48)$. The 268 third cluster contained only zones sampled on the shelf, in 2011 and 2012, and where the diet was 269 dominated by Microsetella (and Corycaeidae in the zone Centre-Shelf-2011). The fourth cluster 270 contained anchovies sampled in the west, on the coast in 2012, feeding almost exclusively on 271 diatoms $(\% \mathrm{IRI}=97.26)$. The fifth cluster had stations sampled in 2012 but unidentified copepods

272 were the main prey. These results show that year and depth were the most important parameters 273 influencing diet. 
a)

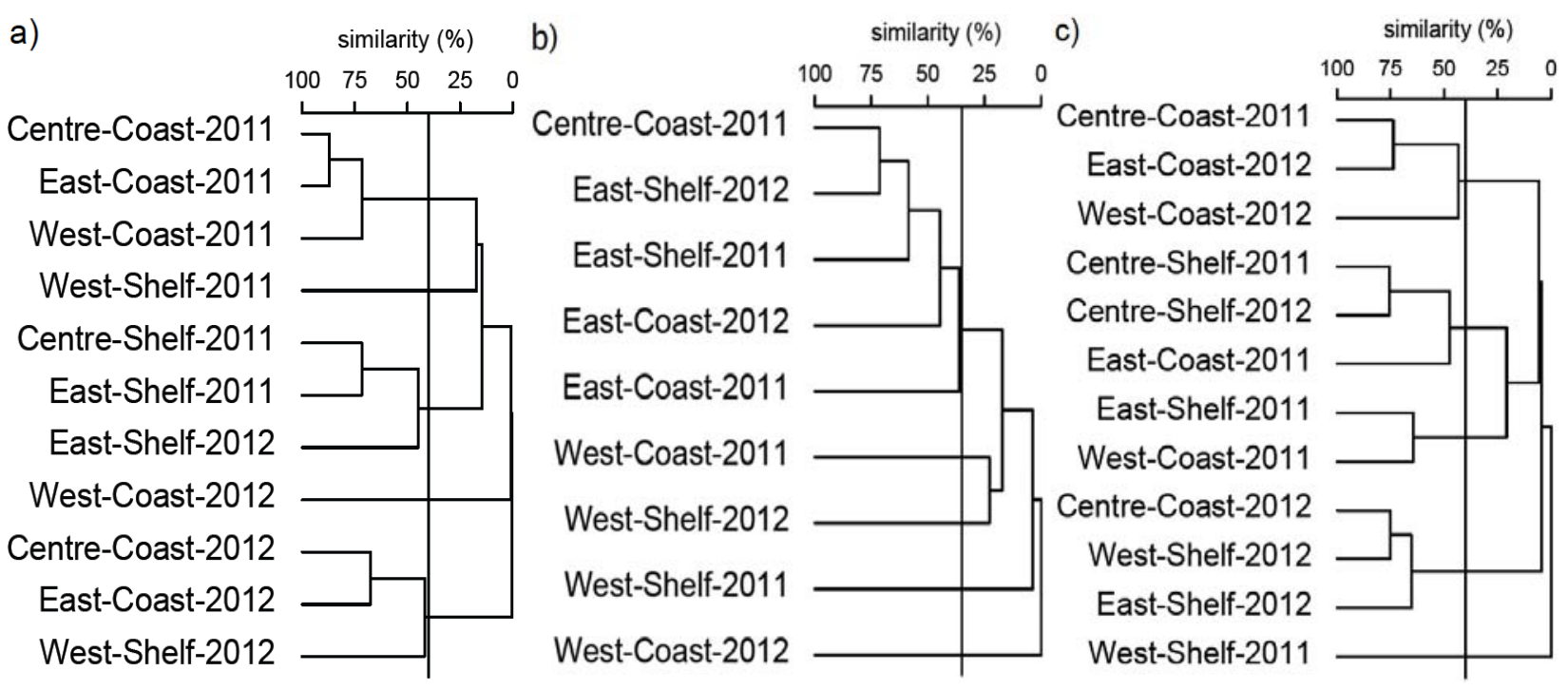

b) $\quad$ similarity $(\%) \quad$ c)

c)

similarity (\%)

276 Fig. 4. Cluster analyses of diet similarities (based on \%IRI) among region, depth and year in a)

277 anchovies, b) sardines, c) sprats. The vertical line separates the clusters.

For sardines, five clusters appeared. The first cluster contained all sardines sampled at the

centre and east of the gulf. The other clusters contained the zones sampled in the west. These results

show that the region has influenced the diet, sardines sampled in the west feeding on various dominating (but there is only one sardine in the cluster West-Shelf-2011) prey among zones (eggs on the coast in 2011, diatoms on the coast in 2012 and unidentified copepods on the shelf in 2012), while sardines of the other regions fed mainly on the copepods usually observed in this study of their diet (Microsetella, Oncaea and Corycaeidae).

Five clusters appeared for sprats. The first contained sprats only sampled on the coast with a diet characterised by Euterpina acutifrons and diverse secondary prey (Oncaea at the centre in 2011, Clauso/Paracalanus in the east in 2012 and Diatoms and Oncaea in the west in 2012). The second contained two zones on the shelf and one on the coast where the diet was characterised by Corycaeidae copepods and Microsetella. The third cluster contained two zones on the coast and on the shelf and in the west and the east. Sprats of this cluster fed on Clauso/Paracalanus and on Corycaeidae. The fourth cluster contained two zones on the shelf and one on the coast but the diet was characterised by unidentified copepods. The last cluster contained the zone West-Shelf-2011 
294 where sprats fed on decapod larvae $(\% \mathrm{IRI}=98.24)$. These results suggest that depth may have

295 influenced sprat diet, with Euterpina acutifrons being a widely consumed prey in coastal zones.

\subsection{Stable isotope analysis}

Isotopic values were significantly different among the three species $(\mathrm{H}=64.028, \mathrm{P}<0.001$

299 for $\delta^{15} \mathrm{~N}, \mathrm{H}=44.843, \mathrm{P}<0.001$ for $\left.\delta^{13} \mathrm{C}\right)$. Anchovies had the lowest $\delta^{15} \mathrm{~N}$ value (mean $\pm \mathrm{SD}=7.5 \pm$ $3000.5 \%$ ) , followed by sprats $\left(7.8 \pm 0.4 \%\right.$ ) and sardines $(8.1 \pm 0.5 \%)$. Anchovies had the highest $\delta^{13} \mathrm{C}$ 301 value $(-19.4 \pm 0.3 \%)$ while sprats and sardines had similar $\delta^{13} \mathrm{C}$ values $(-19.8 \pm 0.6 \%$ for both species). Nevertheless, sprats had a wider range of $\delta^{13} \mathrm{C}$ (from -21.1 to $-17.2 \%$ ) than sardines (from -21.2 to -19.0 , Fig. 5). Anchovies had the smallest isotopic niche (mean $\mathrm{SEA}_{\mathrm{B}}=0.60$ ) while sardines and sprats had similar isotopic niche width (mean $\mathrm{SEA}_{\mathrm{B}}=0.75$ for sardines and 0.79 for sprats).

The influence of the different factors on $\delta^{15} \mathrm{~N}$ and $\delta^{13} \mathrm{C}$ are detailed in Table A.3a and b. In anchovies, $\delta^{15} \mathrm{~N}(\mathrm{t}=5.919, \mathrm{P}<0.001)$ and $\delta^{13} \mathrm{C}(\mathrm{t}=6.398, \mathrm{P}<0.001)$ were dependent on the year of sampling. In 2011, the highest $\delta^{15} \mathrm{~N}$ was observed in the west $(7.5 \pm 0.4 \%)$, the lowest in the centre $(7.1 \pm 0.4 \%)$ and the intermediate value in the east $(7.3 \pm 0.5 \%) . \delta^{13} \mathrm{C}$ slightly increased when the body length increased and was higher in the centre $(-19.4 \pm 0.3 \%$ ), lower in the east $(-19.6 \pm 0.3 \%)$ and intermediate in the west $(-19.5 \pm 0.3 \%)$. The interaction between depth and region showed that offshore anchovies had a higher $\delta^{13} \mathrm{C}$ than coastal anchovies except in the east where coastal anchovies had a higher $\delta^{13} \mathrm{C}$. In 2012, depth had an effect on $\delta^{15} \mathrm{~N}$, with higher $\delta^{15} \mathrm{~N}$ for individuals caught in coastal areas $(8.1 \pm 0.5 \%)$ than on the shelf $(7.7 \pm 0.4 \%$ o $)$ and the interaction between depth and region also influenced $\delta^{15} \mathrm{~N}$ (greater difference between coastal $\delta^{15} \mathrm{~N}$ and offshore $\delta^{15} \mathrm{~N}$ in the centre region). No factor had a significant effect on $\delta^{13} \mathrm{C}$.

In sardines, the year of sampling had no effect on $\delta^{15} \mathrm{~N}(\mathrm{~W}=1123.5, \mathrm{P}=0.428)$ but

318 influenced $\delta^{13} \mathrm{C}(\mathrm{W}=702, \mathrm{P}<0.001) . \delta^{15} \mathrm{~N}$ decreased when body length increased. In $2011, \delta^{13} \mathrm{C}$ 319 increased when the body length increased. In 2012, no factor had a significant effect on $\delta^{13} \mathrm{C}$. 
In sprats, the year of sampling influenced $\delta^{13} \mathrm{C}(\mathrm{W}=458, \mathrm{P}<0.001)$ but not $\delta^{15} \mathrm{~N}(\mathrm{t}=0.080, \mathrm{P}$

$321=0.936) . \delta^{15} \mathrm{~N}$ slightly increased when the body length increased. $\delta^{13} \mathrm{C}$ slightly decreased when

322 body length increased in 2011 but influence of body length on $\delta^{13} \mathrm{C}$ was weak in 2012.

\subsection{Interactions between species}

Diet overlap estimated on $\% \mathrm{IRI}$ and $\% \mathrm{~W}$ was significant for anchovies and sardines $(\% \mathrm{~T}=$

83.91 for \%IRI and 76.92 for $\% \mathrm{~W})$. For sprats and anchovies $(\% \mathrm{~T}=55.06$ for $\% \mathrm{IRI}$ and 65.34 for

$\% \mathrm{~W})$ and for sprats and sardines $(\% \mathrm{~T}=58.51$ for $\% \mathrm{IRI}$ and 64.00 for $\% \mathrm{~W})$, the overlap was nearly

significant when estimated using \%IRI and was significant when using \%W. Diet overlap between

329 length classes is detailed in Table A.4. Anchovies share only $17.12 \%$ of their isotopic niche with 330 sardines (and sardines $12.92 \%$ with anchovies) and $48.46 \%$ with sprats (and sprats $34.48 \%$ with 331 anchovies). Sardines share $48.28 \%$ of their isotopic niche with sprats (and sprats $45.50 \%$ with 332 sardines) (Fig. 5).

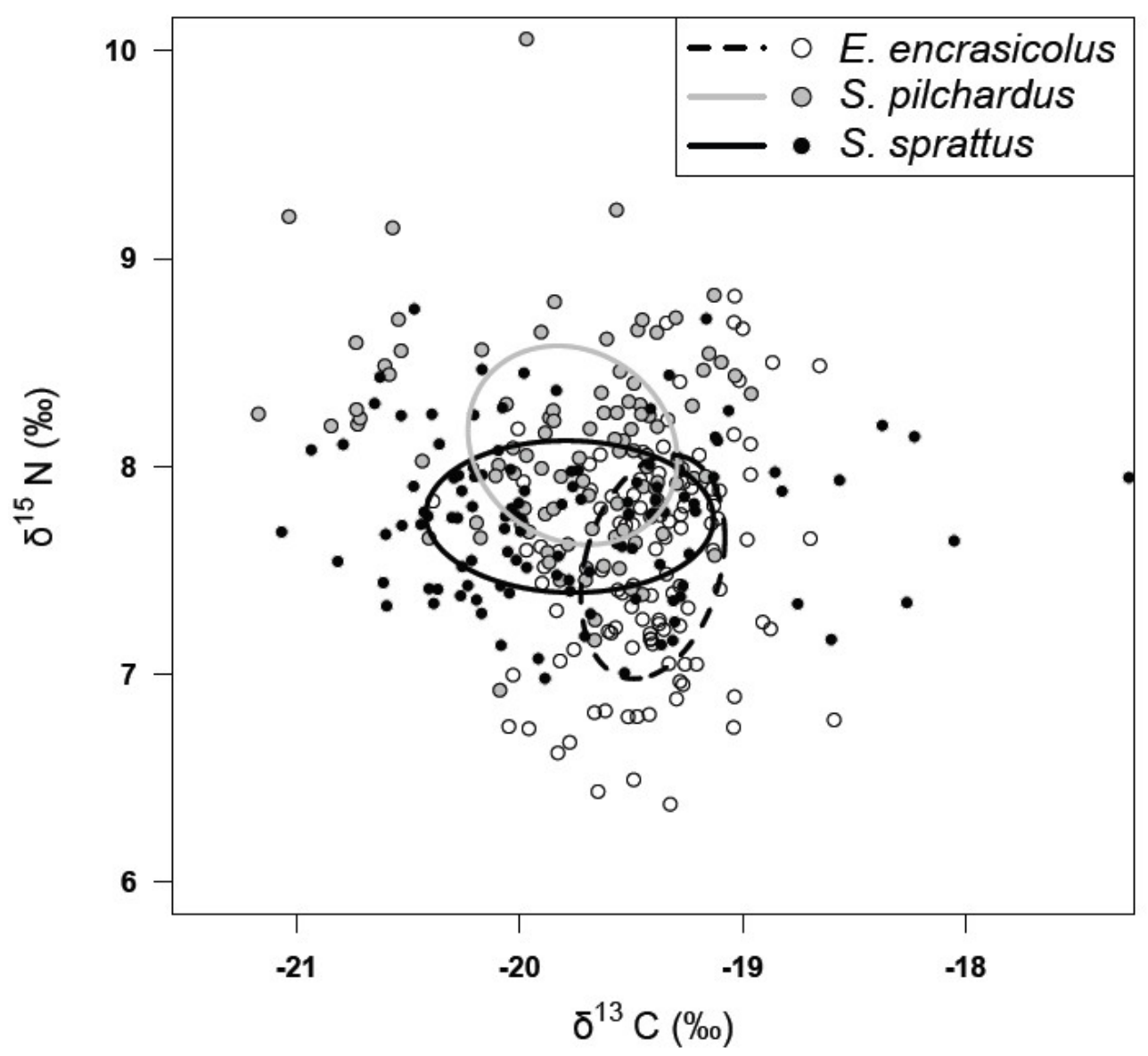


334 Fig. 5. Isotopic values in muscles of anchovies, sardines and sprats and depiction of their niche area 335 using standard ellipses.

\subsection{Relative condition factor}

Sprats had the highest $\mathrm{C} / \mathrm{N}$ ratios (mean $\pm \mathrm{SD}=4.38 \pm 1.12)$, followed by sardines $(3.31 \pm$

$0.14)$ and anchovies $(3.20 \pm 0.09)(\mathrm{H}=148.931, \mathrm{P}<0.001)$. The $\mathrm{C} / \mathrm{N}$ ratios of anchovies were only

340 influenced by the interaction between depth and region (Table A.3c) while $\mathrm{C} / \mathrm{N}$ ratios of sardines

341 were not dependent on any factor. For anchovies, $\mathrm{C} / \mathrm{N}$ ratio did not differ between coastal and

342 offshore regions except in the centre where coastal $\mathrm{C} / \mathrm{N}$ is higher than offshore $\mathrm{C} / \mathrm{N}$. For sprats, $\mathrm{C} / \mathrm{N}$

343 ratios differed between 2011 and $2012(\mathrm{~W}=1093.5, \mathrm{P}=0.002), \mathrm{C} / \mathrm{N}$ ratios being higher in 2012

$344(4.83 \pm 1.36)$ than in $2011(4.03 \pm 0.74)$. The $\mathrm{C} / \mathrm{N}$ ratios of sprats in 2011 and 2012 were higher

345 when body length increased but the other factors were not significant.

\section{Discussion}

\subsection{Diet composition and ontogenetic shifts}

Anchovies fed mainly on Microsetella, Oncaea and Corycaeidae copepods. Consumption of

350 Microsetella has been previously observed in the Gulf of Lions during summer (Plounevez and 351 Champalbert, 2000), Oncaea is a usual prey in other regions of the Mediterranean Sea during other 352 seasons (Bacha and Amara, 2009; Borme et al., 2009; Tudela and Palomera, 1997) and high

353 Corycaeidae copepods consumption has been reported near the Gironde estuary (Plounevez and 354 Champalbert, 1999). Our results contrast with those of Costalago et al. (2012) based on stable 355 isotope analysis where adult anchovies sampled in summer 2008 fed on cladocerans and appendicularians. This contrast suggests that anchovies' summer diet changed between 2007 and 2011-2012. Nevertheless, results on stomach contents of adult anchovies sampled in the 2007-2008 period have not been published yet to confirm the qualitative change in the diet of this age class. Thus, this interpretation should be taken with caution as stomach contents and stable isotopes do 
not provide the same information.

Anchovies had the lowest $\delta^{15} \mathrm{~N}$ and the highest $\delta^{13} \mathrm{C}$. As detritus discharged by the Rhône reduces $\delta^{13} \mathrm{C}$ and increases $\delta^{15} \mathrm{~N}$ of phytoplankton and particulate organic matter in eastern and coastal areas (Harmelin-Vivien et al., 2008), this result indicates that anchovies fed primarily on the continental shelf or in western regions of the Gulf of Lions, far from the Rhône outflow, similarly to what was found in the Bay of Biscay (Chouvelon et al., 2014). The study of the spatial distribution of anchovies in the Gulf of Lions (Saraux et al., 2014) confirms this hypothesis. Anchovies consumed more diatoms and Centropages typicus and less Oncaea when their body length increased. Consumption of Oncaea by small anchovies is in accordance with Costalago et al. (2014) where juveniles sampled in the Gulf of Lions during summer 2007 fed on some Oncaea, even if the dominant prey groups in their study were cladocerans and copepods such as Clauso/Paracalanidae and Centropages typicus. It is the first time that a high contribution of diatoms in the diet of large anchovies was observed in the Gulf of Lions but this has been observed in the Baltic Sea (Schaber et al., 2010). Nevertheless, high diatom consumption has been only observed in one sampling station in 2012 and thus cannot be considered as a general phenomenon. Furthermore, copepods remained the main prey items for anchovies of all length classes. No changes of stable isotope ratios with body length have been detected in anchovies except a slight increase for $\delta^{13} \mathrm{C}$ in 2011 , suggesting few ontogenetic changes in the preferred feeding area.

Microsetella, Oncaea and the Corycaeidae family were also the main prey of sardines. The Oncaea genus was an important prey of adult sardines in the Gulf of Lions during summer 2007 (Costalago and Palomera, 2014) and in other regions (e.g. Garrido et al., 2008; Sever et al., 2005). Our stomach contents results are similar with those of Costalago and Palomera (2014) but cladocerans were an important prey in adult sardines in 2007 (highest \%IRI), which suggests that the dominant prey in the summer diet of sardines might have changed between 2007 and 20112012.

Sardines had the highest $\delta^{15} \mathrm{~N}$ and a low $\delta^{13} \mathrm{C}$, indicating that this species fed mainly on 
coastal or eastern areas of the Gulf of Lions (Harmelin-Vivien et al., 2008), similarly to what was

387 found in the Bay of Biscay (Chouvelon et al., 2014). The study of the spatial distribution of sardines

388 in the Gulf of Lions (Saraux et al., 2014) confirms this hypothesis. High consumption of benthic

389 mysids Paramysis by small sardines in our study shows that juveniles of this species may feed in

390 coastal and benthic habitats. Nevertheless, small juvenile sardines have been sampled only at one

391 station near the Rhône plume and consumption of Paramysis cannot be considered as a general

392 phenomenon in the Gulf of Lions. Costalago and Palomera (2014) and Costalago et al. (2014) have

393 reported that juvenile sardines of the Gulf of Lions fed mainly on cladocerans and decapod larvae

394 during summer 2007. Like anchovies, sardines consumed more diatoms when their body length

395 increased but this observation is limited to one sampling station. A high contribution of

396 photosynthetic organisms in the diet of adult sardines has been previously observed (e.g. Garrido et

397 al., 2008) but these prey are poorly assimilated (Bode et al., 2004; Costalago and Palomera, 2014;

398 Nikolioudakis et al., 2012). Copepods remained the main prey items for large juvenile and adult

399 sardines. High consumption of Paramysis by small sardines and consumption of diatoms by large

400 sardines explain the decrease of the size of the prey when the sardines are growing and may be

401 linked to the acquisition of filter feeding ability thanks to gill rakers development (Costalago and

402 Palomera, 2014). $\delta^{13} \mathrm{C}$ increased while $\delta^{15} \mathrm{~N}$ decreased when body length increased in 2011,

403 indicating that juvenile sardines fed in areas influenced by the Rhône inputs while adult sardines fed

404 in more oligotrophic areas with marine phytoplankton being the main carbon source.

405 Sprats were more generalist and fed on Clauso/Paracalanus, the Corycaeidae family,

406 Euterpina acutifrons and Microsetella. By contrast, adult sprats feed mainly on the copepods

407 Calanus and Temora in the Adriatic Sea (Tičina et al., 2000) but important consumption of

408 Microsetella was detected in term of number in a Norwegian fjord (Falkenhaug and Dalpadado,

409 2014). Sprats also had the lowest predator/prey ratios compared to sardines and anchovies,

410 indicating that they fed on the largest prey relative to their size. The consumption of larger prey

411 compared to its own size may be explained by the fact that sampled sprats are mostly juveniles (de 
412 Silva, 1973) and thus have a lesser filter-feeding capacity. The absence of changes in prey sizes for

413 anchovies and sprats is thus likely the result of a lower size range available for these species.

414 Sprats had an intermediate $\delta^{15} \mathrm{~N}$ and a $\delta^{13} \mathrm{C}$ value very similar to the $\delta^{13} \mathrm{C}$ value of sardines but

415 with a wider range. Consequently, the mean $\delta^{13} \mathrm{C}$ value indicates that sprats fed mainly on coastal or

416 eastern areas of the Gulf of Lions, probably in the same areas as sardines, but the range also indicate

417 that they may feed on the shelf.

418 Whatever their size, sprats fed more on larger copepods. The contribution of Oncaea to the 419 diet decreased with increasing body length while the contribution of Corycaeidae increased. $\delta^{15} \mathrm{~N}$ 420 increased with body length, indicating increasing trophic level while growing as they fed less on 421 omnivorous Oncaea (Wu et al., 2004) and more on the predatory Corycaeidae copepods (Landry et 422 al., 1985; Turner et al., 1984). $\delta^{13} \mathrm{C}$ decreased in 2011, indicating that sprats may exploit food webs 423 influenced by Rhône inputs while growing as $\delta^{13} \mathrm{C}$ is lower in waters influenced by the Rhône 424 plume (Harmelin-Vivien et al., 2008).

\subsection{Spatial and temporal variations of diet}

Diet of anchovies differed between 2011 and 2012 and between coast and shelf. In 2011, coastal anchovies fed mainly on Oncaea while Microsetella was the main prey on the shelf. Only

429 few anchovies were sampled in coastal areas by Plounevez and Champalbert (2000), which may explain the high importance of Microsetella and the low importance of Oncaea in the general diet of anchovies sampled in their study. Diet of anchovies in the western region was quite unusual, with

432 high consumption of Euphausiacean larvae on the shelf in 2011 and of diatoms on the coast in 2012. 433 Plounevez and Champalbert (2000) observed differences of feeding between west and east for 434 offshore anchovies, with Euphasiacean larvae being an important prey for western anchovies in 4351995 and Microsetella being an important prey for eastern anchovies in 1995 and 1996. In 2011, 436 stable isotope ratios were dependent on the region of sampling and, in $2012, \delta^{15} \mathrm{~N}$ was influenced by depth. Anchovies sampled in 2011 in the eastern region showed higher $\delta^{13} \mathrm{C}$ in the coastal area than 
438 on the shelf. This result was not in accordance with low $\delta^{13} \mathrm{C}$ observed in particulate organic matter

439 (Harmelin-Vivien et al., 2008) but was in accordance with high values of $\delta^{13} \mathrm{C}$ recorded in

440 zooplankton sampled near the Rhône river as this zooplankton previously fed in an offshore area

441 characterised by higher $\delta^{13} \mathrm{C}$ values (Espinasse et al., 2014b). No spatial pattern was found in the

442 Bay of Biscay, indicating high mobility of anchovies in this region (Chouvelon et al., 2014). In the

443 Gulf of Lions, different stable isotope ratios between regions in 2011 or between depths in 2012

444 may indicate that anchovy schools may have preferences in feeding areas.

445 Diet of sardines differs among regions of the Gulf of Lions. Sardines sampled in the centre 446 and the east fed mainly on Microsetella, Oncaea and Corycaeidae, while sardines sampled in the 447 west had a more diverse diet (eggs on the coast in 2011, diatoms on the coast in 2012). As in the 448 Bay of Biscay (Chouvelon et al., 2014), stable isotope ratios of sardines did not vary among regions 449 or depths of sampling, except in 2011 on the eastern coast where $\delta^{13} \mathrm{C}$ was low, suggesting high 450 mobility of sardines.

Diet of sprats differs between coastal areas and continental shelf and diet was dominated by

452 decapod larvae on the western shelf. In 2012, diatoms are a secondary prey in the west and on the 453 coast, suggesting that sprat is more carnivorous than anchovies and sardines. This result is in 454 accordance with those of Pethybridge et al. (2014) where sprat sampled during winter 2011 had 455 higher fatty acid markers of carnivory than anchovies and sardines. No spatial variations of stable 456 isotope ratios were observed in sprats, indicating high mobility of sprat schools in the Gulf of 457 Lions. Higher diversity and variability of dominating prey in the west of the Gulf of Lions for the 458 three species may be the result of differences of habitat conditions (Espinasse et al., 2014a).

\subsection{Interaction between planktivorous teleost species}

Trophic competition has been speculated in areas where planktivorous teleost species cooccur (Casini et al., 2004; Raab et al., 2012). Our stomach contents results indicate high trophic interactions between anchovies, sardines and sprats in the Gulf of Lions as diet overlap occurs in 
464 their general diet, notably between anchovies and sardines. $\delta^{13} \mathrm{C}$ values indicate that sardines and

465 sprats fed in the same areas. In contrast, trophic interactions of anchovies with sardines and sprats

466 are potentially reduced considering their differences in $\delta^{13} \mathrm{C}$. The isotopic niche of sprats based on

467 both $\delta^{13} \mathrm{C}$ and $\delta^{13} \mathrm{~N}$ ratios highly overlapped with those of anchovies and sardines, suggesting that

468 sprats compete with the two other species, while the isotopic niches of anchovies and sardines

469 poorly overlapped, suggesting that they fed in different areas considering their distribution (Saraux

470 et al., 2014). Pethybridge et al. (2014) have also observed reduced competition between anchovies

471 and sardines by using lipid biomarkers. Consequently, contrasting results were obtained on trophic

472 interactions between anchovies and sardines with stomach content and stable isotopes, suggesting

473 overlap for the recently ingested prey but not for the previously ingested prey and/or the feeding

474 areas. However, results on stable isotope ratios should be considered with caution as these

475 potentially migratory species feed in an area subjected to high inputs and hydrological variations

476 (Espinasse et al., 2014a; Harmelin-Vivien et al., 2008). These factors may also explain the high

477 differences noticed in the trophic niche overlap when using diet indices (\%IRI and \%W) and stable

478 isotope ratios.

Differences of $\delta^{15} \mathrm{~N}$ in anchovies between coast and continental shelf in 2012 indicate that

some anchovies may sometimes exploit mainly coastal areas with sardines and sprats instead of the

continental shelf, leading to high local trophic overlap between the three species. Adult anchovies

of the Bay of Biscay feed primarily in offshore habitats (Chouvelon et al., 2014) but Pasquaud et al.

(2008) observed that small anchovies can also feed along with sprats in estuarine habitats of the

484 Gironde. If competition between the three species occurs in the Gulf of Lions, sprats should have an advantage considering their larger niche width, the feeding on slightly larger, and thus, more energetic prey (Gerking, 1994; van Deurs et al., 2015) than anchovies and sardines, their lowest predator/prey size ratios and because they seem to recover well after the spawning period (Pethybridge et al., 2014). 
490 information, the changes in the diets of anchovies and sardines reported from 1995-1996

491 (Plounevez and Champalbert, 2000) to 2007-2008 (Costalago et al., 2012; Costalago and Palomera,

492 2014) and to 2011-2012 (this study) may have been a contributing factor to the decline of anchovies

493 and sardines. Consumption of cladocerans by the three species is variable among regions with, for

494 examples, a good representation of this group in the general diet of sardines of the Aegean sea

495 (Nikolioudakis et al., 2012) and sprats of the Baltic Sea and of the North Sea (Casini et al., 2004;

496 Raab et al., 2012) but a low importance in western Mediterranean Sea (Borme et al., 2009;

497 Plounevez and Champalbert, 2000; Tičina et al., 2000) except at local scale (Tudela and Palomera,

498 1997). Furthermore, cladocerans are considered to have lower energetic value than copepods (Bodt

499 and Haldorson, 2002). Consequently, unusual consumption of cladocerans in 2007-2008, while it

500 was rare in 1995-1996 and 2011-2012, may have had a negative impact on the body condition of

501 adult anchovies and sardines, leading to the decreasing biomass observed for these species since

502 2008. Decreasing biomass of anchovies and sardines after such events may have led to an increase

503 in sprat biomass and competition may have prevented the recovery of anchovies and sardines,

504 leading to persistence of the phenomenon. However, competition only occurs when food resources

505 are limited for the predators and no information regarding this factor exists for the study area or

506 elsewhere for these species. Furthermore, body condition of anchovies and sardines was still low in

5072011 and 2012 despite the fact that they ate more copepods and less cladocerans than in the past

508 years (Van Beveren et al., 2014). Consequently, other environmental and/or physiological factors

509 (Cury and Roy, 1989; Takasuka et al., 2007) may have acted in interaction with the trophic one to

510 influence the body condition and/or biomass of small pelagic teleosts. However, the relationship

511 between body condition of anchovies and sardines and mesozooplankton concentration (Brosset et

512 al., in press) indicates that the decline of these species is mainly explained by the trophic ecology of

513 these species. The importance of competition may possibly vary seasonally. In the Gulf of Lions,

514 Pethybridge et al. (2014) reported that no competition of sprats with anchovies and sardines during

515 winter 2011 was apparent on the basis of lipid biomarkers. In the Bay of Biscay, Chouvelon et al. 
516 (2015) hypothesised that anchovies and sardines are potential competitors for food in autumn, but

517 not in spring.

\section{4. $C / N$ ratios as an indicator of relative condition}

Sprats had the highest $\mathrm{C} / \mathrm{N}$ ratios, followed by sardines and anchovies, suggesting that this

species has the highest lipid levels and thus the best relative condition in the Gulf of Lions during summer. That does not imply the good "health" of this population over the time as sprats had a

523 lower relative condition value and a small length when compared to previous years (Van Beveren et al., 2014). Low fat content in anchovies was related to the spawning activity that occurs in summer (Palomera et al., 2007). Higher fat content in sardines than in anchovies has been observed in various seasons (Sánchez et al., 2013; Zlatanos and Laskaridis, 2007).

Sprats sampled during winter 2011 had also higher lipid contents than anchovies and sardines

528 (Pethybridge et al., 2014), suggesting that they had the best relative condition throughout the year when compared to sardines and anchovies. Slight increase of $\mathrm{C} / \mathrm{N}$ ratios occurred only in sprats when they are growing, suggesting that larger sprats increase their chances of survival. As a result, sprats are at an advantage when they compete with anchovies and sardines. The greater niche width and the consumption of slightly larger prey may contribute to the better relative condition of sprats.

\section{Conclusion}

Combining stomach content analysis with stable isotopes is necessary to better understand trophic ecology of small pelagic teleosts within a region subjected to variable hydrological conditions, to different sources of particulate organic matter and variable plankton communities (Espinasse et al., 2014a). The studied species changed their summer diet compared to past studies. The trophic niche overlap between the three species sustains the hypothesis of their competition, but data on the quality and quantity of zooplankton are necessary to confirm or disprove the hypothesis on the limitation of food resources. However, the higher diversity and size of the consumed prey, 
542 trophic niche and $\mathrm{C} / \mathrm{N}$ values of sprats indicate that they probably have a competitive advantage

543 over anchovies and sardines and thus a trophic factor may be one of the explaining factors of the

544 recent changes in small pelagic teleost communities of the Gulf of Lions.

\section{Acknowledgements}

547 Thanks are expressed to the crew of the R.V. 'l'Europe' and to Bourdeix J. H., Brisset B., Metral

548 L., Roos D., Biton Porsmoguer S., Delpy F., Ourgaud M. for help in sampling during the PELMED

549 and MEDITS campaigns, to De Braux E., Houssard P., Michelot C., Monnier N., Morat F., for 550 treatment of some samples in the laboratory, to Cresson P. for help in data analysis, to Peron C. for

551 funding some analyses, to Harmelin-Vivien M. and Menard F. for suggestions on the manuscript 552 and to Michael Paul for improvement of the English. We thank the two anonymous reviewers for 553 their helpful comments. This study was funded by the programs EcoPelGol FFP, EMIBIOS FRB, 554 IPP WP2-MERMEX and PERSEUS FP7 EU project.

\section{References}

Arculeo, M., Froglia, C. and Riggio, S., 1993. Food partitioning between Serranus scriba and Scorpaena porcus (Perciformes) on the infralittoral groud of the South Tyrrhenian Sea. Cybium 17, 251-258.

Bacha, M., Amara, R., 2009. Spatial, temporal and ontogenetic variation in diet of anchovy (Engraulis encrasicolus) on the Algerian coast (SW Mediterranean). Estuarine, Coastal and Shelf Science 85, 257-264.

Banaru, D., Mellon-Duval, C., Roos, D., Bigot, J.L., Souplet, A., Jadaud, A., Beaubrun, P., Fromentin, J.M., 2013. Trophic structure in the Gulf of Lions marine ecosystem (northwestern Mediterranean Sea) and fishing impacts. Journal of Marine Systems 111-112, 4568.

567 Bode, A., Álvarez-Ossorio, M.T., Carrera, P., Lorenzo, J., 2004. Reconstruction of trophic 
pathways between plankton and the North Iberian sardine (Sardina pilchardus) using stable isotopes. Scientia Marina 68, 165-178.

570 Boldt, J.L., Haldorson, L.J., 2002. A bioenergetics approach to estimating consumption of zooplankton by juvenile pink salmon in Prince William Sound, Alaska. Alaska Fishery Research Bulletin 9, 111-127.

Borme, D., Tirelli, V., Brandt, S.B., Fonda Umani, S., Arneri, E., 2009. Diet of Engraulis encrasicolus in the northern Adriatic Sea (Mediterranean): ontogenetic changes and feeding selectivity. Marine Ecology Progress Series 392, 193-209.

Borsa, P., Collet, A., Durand, J.D., 2004. Nuclear-DNA markers confirm the presence of two anchovy species in the Mediterranean. Comptes Rendus Biologies 327, 1113-1123.

Brodeur, R.D., Suchman, C.L., Reese, D.C., Miller, T.W., Daly, E.A., 2008. Spatial overlap and trophic interactions between pelagic fish and large jellyfish in the northern California Current. Marine Biology 154, 649-659.

Brosset, P., Ménard, F., Fromentin, J.M., Bonhommeau, S., Ulses, C., Bourdeix, J.H., Bigot, J.L., Van Beveren, E., Roos, D., Saraux, C. Influence of environmental variability and age on small pelagic fish body condition in the Gulf of Lions. Marine Ecology Progress Series (2015). http://dx.doi.org/10.3354/meps11275

Casini, M., Cardinale, M., Arrhenius, F., 2004. Feeding preferences of herring (Clupea harengus) and sprat (Sprattus sprattus) in the southern Baltic Sea. ICES Journal of Marine Science $61,1267-1277$.

Chouvelon, T., Chappuis, A., Bustamante, P., Lefebvre, S., Mornet, F., Guillou, G., Violamer, L., Dupuy, C., 2014. Trophic ecology of European sardine Sardina pilchardus and European anchovy Engraulis encrasicolus in the Bay of Biscay (north-east Atlantic) inferred from $\delta^{13} \mathrm{C}$ and $\delta^{15} \mathrm{~N}$ values of fish and identified mesozooplanktonic organisms. Journal of Sea Research 85, 277-291. 
C., 2015. Small pelagic fish feeding patterns in relation to food resourcevariability: an isotopic investigation for Sardina pilchardus and Engraulis encrasicolus from the Bay of Biscay (north-east Atlantic). Marine Biology 162, 15-37.

600 Costalago, D., Navarro, J., Álvarez-Calleja, I., Palomera, I., 2012. Ontogenetic and seasonal 601 changes in the feeding habits and trophic levels of two small pelagic fish species. Marine

Cury, P., Roy, C., 1989. Optimal environmental window and pelagic fish recruitment success in upwelling areas. Canadian Journal of Fisheries and Aquatic Sciences 46, 670-680. Ecology Progress Series 460, 169-181.

Costalago, D., Palomera, I., 2014. Feeding of European pilchard (Sardina pilchardus) in the northwestern Mediterranean: from late larvae to adults. Scientia Marina 78, 41-54.

Costalago, D., Palomera, I., Tirelli, V., 2014. Seasonal comparison of the diets of juvenile European anchovy Engraulis encrasicolus and sardine Sardina pilchardus in the Gulf of Lions. Journal of Sea Research 89, 64-72.

Cruzado, A., Velasquez, Z.R., 1990. Nutrients and phytoplankton in the Gulf of Lions, northwestern Mediterranean. Continental Shelf Research 10, 931-942.

Cury, P., Bakun, A., Crawford, R.J.M., Jarre, A., Quiñones, R.A., Shannon, L.J., Verheye, H.M., 2000. Small pelagics in upwelling systems: patterns of interaction and structural changes in “wasp-waist” ecosystems. ICES Journal of Marine Science 57, 603-618.

Cury, P.M., Boyd, I.L., Bonhommeau, S., Anker-Nilssen, T.A., Crawford, R.J.M., Furness, R.W., Mills, J.A., Murphy, E.J., Österblom, H., Paleczny, M., Piatt, J.F., Roux, J.P., Shannon, L., Sydeman, W.J., 2011. Global seabird response to forage fish depletion-one-third for the birds. Science 334, 1703-1706. 
feeding signatures of Atlantic salmon in the North Atlantic. ICES Journal of Marine Science 67, 52-61.

622 Denis, L., Grenz, C., 2003. Spatial variability in oxygen and nutrient fluxes at the sediment-water interface on the continental shelf in the Gulf of Lions (NW Mediterranean). Oceanologica Acta 26, 373-389.

de Silva, S.S., 1973. Aspects of the reproductive biology of the sprat, Sprattus sprattus (L.) in inshore waters of the west coast of Scotland. Journal of Fish Biology 5, 689-705.

Espinasse, B., Carlotti, F., Zhou, M., Devenon, J.L., 2014a. Defining zooplankton habitats in the Gulf of Lion (NW Mediterranean Sea) using size structure and environmental conditions. Marine Ecology Progress Series 506, 31-46.

Espinasse, B., Harmelin-Vivien, M., Tiano, M., Guilloux, L., Carlotti, F., 2014b. Patterns of variations in $\mathrm{C}$ and $\mathrm{N}$ stable isotope ratios in size-fractionated zooplankton in the Gulf of Lion, NW Mediterranean Sea. Journal of Plankton Research 36, 1204-1215.

Falkenhaug, T., Dalpadado, P., 2014. Diet composition and food selectivity of sprat (Sprattus sprattus) in Hardangerfjord, Norway. Marine Biology Research 10, 203-215.

Garrido, S., Ben-Hamadou, R., Oliveira, P.B., Cunha, M.E., Chícharo, M.A., van der Lingen, C.D., 2008. Diet and feeding intensity of sardine Sardina pilchardus: correlation with satellitederived chlorophyll data. Marine Ecology Progress Series 354, 245-256.

Gerking, S.D., 1994. Feeding ecology of fish. Academic Press, San Diego. 416 pp.

Harmelin-Vivien, M., Loizeau, V., Mellon, C., Beker, B., Arlhac, D., Bodiguel, X., Ferraton, F.,

Hobson, K.A., 1999. Tracing origins and migration of wildlife using stable isotopes: a review. Oecologia 120, 314-326. ratios between surface particulate organic matter and microphytoplankton in the Gulf of Lions (NW Mediterranean). Continental Shelf Research 28, 1911-1919. 
of Fish Biology 17, 411-429.

647 Jackson, A.L., Inger, R., Parnell, A.C., Bearhop, S., 2011. Comparing isotopic niche widths among and within communities: SIBER - Stable Isotope Bayesian Ellipses in R. Journal of Animal Ecology 80, 595-602.

Köster, F.W., Möllmann, C. 2000. Trophodynamic control by clupeid predators on recruitment success in Baltic cod? ICES Journal of Marine Science 57, 310-323.

Landry, M.R., Lehner-Fournier, J.M., Fagerness, V.L., 1985. Predatory feeding behavior of the marine cyclopoid copepod Corycaeus anglicus. Marine Biology 85, 163-169.

Logan, J.M, Jardine, T.D., Miller, T.J., Bunn, S.E., Cunjak, R.A., Lutcavage, M.E., 2008.Lipid corrections in carbon and nitrogen stable isotope analyses: comparison of chemical extraction and modelling methods. Journal of Animal Ecology 77, 838-846.

Michener, R.H., Kaufman, L., 2007. Stable isotope ratios as tracers in marine food webs: an update. In: Michener R., Lajtha, K. (eds.), Stable Isotopes in Ecology and Environmental Science, pp. 238-282. Blackwell Publishing, Malden.

Nikolioudakis, N., Isari, S., Pitta, P., Somarakis, S., 2012. Diet of sardine Sardina pilchardus: an ‘end-to-end' field study. Marine Ecology Progress Series 453, 173-188.

Palomera, I., Olivar, M.P., Salat, J., Sabatés, A., Coll, M., Garciá, A., Morales-Nin, B., 2007. Small pelagic fish in the NW Mediterranean Sea: An ecological review. Progress in Oceanography 74, 377-396.

Parnell, A.C., Inger, R., Bearhop, S., Jackson, A.L., 2010. Source partitioning using stable isotopes: coping with too much variation. PLoS ONE 5, e9672.

Pasquaud, S., Elie, P., Jeantet, C., Billy, I., Martinez, P., Girardin, M., 2008. A preliminary investigation of the fish food web in the Gironde estuary, France, using dietary and stable isotope analyses. Estuarine, Coastal and Shelf Science 78, 267-279.

Pethybridge, H., Bodin, N., Arsenault-Pernet, E.J., Bourdeix, J.H., Brisset, B., Bigot, J.L., Roos, D., Peter, M., 2014. Temporal and inter-specific variations in forage fish feeding conditions in 
the NW Mediterranean: lipid content and fatty acid compositional changes. Marine Ecology Progress Series 512, 39-54.

674 Pinkas, L.M., Oliphant, S., Iverson, I.L.K., 1971. Food habits of albacore, bluefin tuna and bonito in Californian waters. Fish Bulletin. California Department of Fish and Game 152, 1-105.

Plounevez, S., Champalbert, G., 1999. Feeding Behaviour and Trophic Environment of Engraulis encrasicolus (L.) in the Bay of Biscay. Estuarine, Coastal and Shelf Science 49, 177-191. (Engraulis encrasicolus) in the Gulf of Lions. Oceanologica Acta 23, 175-192.

Post, D.M., Layman, C.A., Arrington, D.A., Takimoto, G., Quatrochi, J., Montana, C.G., 2007. Getting to the fat of matter: models, methods and assumptions for dealing with lipids in stable isotope analysis. Oecologia 152, 179-189.

Purcell, J.E., Sturdevant, M.V., 2001. Prey selection and dietary overlap among zooplanktivorous jellyfish and juvenile fishes in Prince William Sound, Alaska. Marine Ecology Progress Series 210, 67-83.

Raab, K., Nagelkerke, L.A.J., Boerée, C., Rijnsdorp, A.D., Temming, A., Dickey-Collas, M., 2012. Dietary overlap between the potential competitors herring, sprat and anchovy in the North Sea. Marine Ecology Progress Series 470, 101-111.

Sánchez, S., Palomera, I., Albo-Puigserver, M., Bernal, M., 2013. Energy density and lipid content of sardine (Sardina pilchardus) and anchovy (Engraulis encrasicolus) in the Catalan Sea, Northwestern Mediterranean Sea. 40 ${ }^{\text {th }}$ CIESM Congress Proceedings 40, 530.

Saraux, C., Fromentin, J.M., Bigot, J.L., Bourdeix, J.H., Morfin, M., Roos, D., Van Beveren, E., Bez, N. 2014. Spatial Structure and Distribution of Small Pelagic Fish in the Northwestern Mediterranean Sea. PLoS ONE 9, e111211. ctenophore Mnemiopsis leidyi and ichthyoplankton in the Bornholm Basin (Baltic Sea). 
Schaber, M., Petereit, C., Paulsen, M., 2010. Diet composition of European anchovy Engraulis encrasicolus in Kiel Bight, western Baltic Sea. Journal of Fish Biology 76, 1856-1862.

701 Schoener, T.W., 1970. Non-synchronous spatial overlap of lizards in patchy habits. Ecology 51, 408-418.

Sever, T.M., Bayhan, B., Taskavak, E., 2005. A preliminary study on the feeding regime of

Sweeting, C.J., Polunin, N.V.C., Jennings, S., 2006. Effects of chemical lipid extraction and arithmetic lipid correction on stable isotope ratios of fish tissues. Rapid Communications in Mass Spectrometry 20, 595-601.

Takasuka, A., Oozeki, Y., Aoki, I., 2007. Optimal growth temperature hypothesis: Why do anchovy flourish and sardine collapse or vice versa under the same ocean regime? Canadian Journal

Tičina, V., Vidjak, O., Kačič, I., 2000. Feeding of adult sprat, Sprattus sprattus, during spawning season in the Adriatic Sea. Italian Journal of Zoology 67, 307-311.

Turner, J.T., Tester, P.A., Conley, W.J., 1984. Zooplankton feeding ecology: predation by the marine cyclopoid copepod Corycaeus amazonicus F. Dahl upon natural prey. Journal of Experimental Marine Biology and Ecology 84, 191-202. 
724 van Deurs, M., Jørgensen, C., Fiksen, Ø., 2015. Effects of copepod size on fish growth: a model 725 based on data for North Sea sandeel. Marine Ecology Progress Series 520, 235-243.

726 Verheye, H.M., Richardson, A.J., 1998. Long-term increase in crustacean zooplankton abundance in the southern Benguela upwelling region (1951-1996): bottom-up or top-down control? ICES Journal of Marine Science 55, 803-807.

729 Wu, C.H., Hwang, J.S., Yang, J.S., 2004. Diets of three copepods (Poecilostomatoida) in the $730 \quad$ Southern Taiwan Strait. Zoological Studies 43, 388-392.

731 Zlatanos, S., Laskaridis, K., 2007. Seasonal variation in the fatty acid composition of three 732 Mediterranean fish - sardine (Sardina pilchardus), anchovy (Engraulis encrasicholus) and picarel (Spicara smaris). Food Chemistry 103, 725-728. 


\section{Supplementary material: Trophic niche overlap of sprat and commercial small pelagic teleosts}

\section{in the Gulf of Lions (NW Mediterranean Sea)}

B. Le Bourg, D. Banaru, C. Saraux, A. Nowaczyk, E. Le Luherne, A. Jadaud, J.L. Bigot, P. Richard

Table A.1. Dry weight (DW; $\mu \mathrm{g}$ ) of prey and morphometric relationship used to calculate DW. TL $=$ Total length $(\mu \mathrm{m})$.

\begin{tabular}{|c|c|c|c|}
\hline & Prey & Dry weight $(\mu \mathrm{g})$ & Reference \\
\hline $\begin{array}{l}\text { Protists } \\
\text { Protists } \\
\text { Crustaceans }\end{array}$ & Protists & $\mathrm{DW}=30$ & This study \\
\hline Copepods & $\begin{array}{l}\text { Clauso/Paracalanus, } \\
\text { Pleuromamma and } \\
\text { copepods n.d. } \\
\text { Calanus } \\
\text { Microsetella } \\
\text { Oncaea } \\
\text { Corycaeidae } \\
\text { Euterpina acutifrons } \\
\text { Macrosetella } \\
\text { Centropages typicus } \\
\text { Centropages hamatus } \\
\text { Candacia } \\
\text { Oithona } \\
\text { Temora } \\
\text { Euchaeta } \\
\text { Acartia } \\
\text { Lucicutia } \\
\text { Clytemnestra }\end{array}$ & 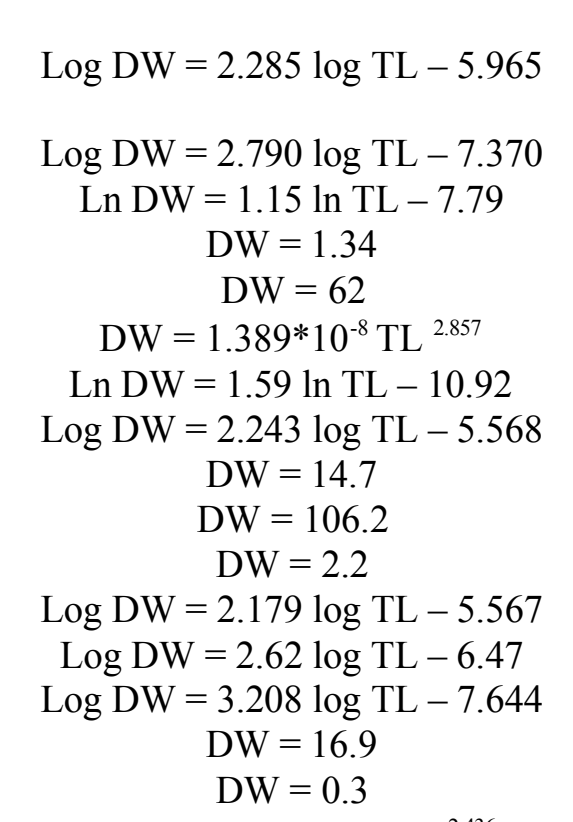 & $\begin{array}{l}\text { Mauchline (1998) } \\
\text { Mauchline (1998) } \\
\text { Satapoomin (1999) } \\
\text { Borme et al. (2009) } \\
\text { Pitois \& Fox (2006) } \\
\text { Ara (2001) } \\
\text { Satapoomin (1999) } \\
\text { Mauchline (1998) } \\
\text { Pitois \& Fox (2006) } \\
\text { Pitois \& Fox (2006) } \\
\text { Pitois \& Fox, 2006 } \\
\text { Mauchline (1998) } \\
\text { Uye (1982) } \\
\text { Mauchline (1998) } \\
\text { Delpy (2013) } \\
\text { Delpy (2013) }\end{array}$ \\
\hline Cladocerans & $\begin{array}{l}\text { Evadne } \\
\text { Podon } \\
\text { Cladocerans n.d. } \\
\text { Ostracods }\end{array}$ & $\begin{array}{c}\mathrm{DW}=3.946(\mathrm{TL} / 1000)^{2.436} \\
\mathrm{DW}=1.6 \\
\text { mean Evadne and Podon } \\
\mathrm{DW}=6.036\end{array}$ & $\begin{array}{l}\text { Borme et al. (2009) } \\
\text { Borme et al. (2009) } \\
\text { This study } \\
\text { Borme et al. (2009) }\end{array}$ \\
\hline $\begin{array}{l}\text { Mysids } \\
\text { Amphipods }\end{array}$ & $\begin{array}{l}\text { Paramysis } \\
\text { Phronima } \\
\text { Other amphipods }\end{array}$ & $\begin{array}{c}\log \mathrm{DW}=3.08 \log \mathrm{TL}+0.236 \\
\mathrm{DW}=40 ; \mathrm{DW}=770 \\
\mathrm{DW}=40\end{array}$ & $\begin{array}{l}\text { Uye (1982) (Neomysis) } \\
\text { This study } \\
\text { This study }\end{array}$ \\
\hline $\begin{array}{l}\text { Isopods } \\
\text { Chaetognaths } \\
\text { Chaetognaths } \\
\text { Larvae }\end{array}$ & Chaetognaths & $\begin{array}{c}\mathrm{Ln} \mathrm{DW}=1.69 \ln (\mathrm{TL} / 1000)-11.64 \\
\log \mathrm{DW}=3.24 \log \mathrm{TL}-0.975\end{array}$ & Borme et al. (2009) \\
\hline Crustaceans & $\begin{array}{l}\text { Copepodids } \\
\text { Nauplii } \\
\text { Cirriped nauplii } \\
\text { Protozoea } \\
\text { Metazoea } \\
\text { Brachyurans } \\
\text { Decapods } \\
\text { Zoea } \\
\text { Trachelifer } \\
\text { Euphausiaceans }\end{array}$ & $\begin{array}{c}\mathrm{DW}=1.10^{*} 10^{-5} \mathrm{TL}^{1.89} \\
\log \mathrm{DW}=2.848 \log \mathrm{TL}-7.265 \\
\mathrm{DW}=0.67 \\
\mathrm{DW}=27.798 \\
\mathrm{DW}=27.798 \\
\mathrm{DW}=27.798 \\
\mathrm{DW}=27.798 \\
\mathrm{DW}=27.798 \\
\mathrm{DW}=27.798 \\
\text { Log DW }=0.456+2.8 \log \mathrm{TL}\end{array}$ & $\begin{array}{l}\text { Dumont et al. (1975) } \\
\text { Borme et al. (2009) } \\
\text { Borme et al. (2009) } \\
\text { Borme et al. (2009) } \\
\text { Borme et al. (2009) } \\
\text { Borme et al. (2009) } \\
\text { Borme et al. (2009) } \\
\text { Borme et al. (2009) } \\
\text { Borme et al. (2009) } \\
\text { Lindley et al. (1999) }\end{array}$ \\
\hline Molluscs & $\begin{array}{l}\text { Gastropods } \\
\text { Bivalves }\end{array}$ & $\begin{array}{c}\mathrm{DW}=0.6 \\
\mathrm{DW}=3.758\end{array}$ & $\begin{array}{l}\text { Borme et al. (2009) } \\
\text { Borme et al. (2009) }\end{array}$ \\
\hline $\begin{array}{l}\text { Teleosts } \\
\text { Eggs }\end{array}$ & Teleosts & $\mathrm{DW}=7510$ & This study \\
\hline Eggs & Anchovies eggs & $\mathrm{DW}=30.1$ & Borme et al. (2009) \\
\hline
\end{tabular}


Table A.2. Frequency of occurrence $(\% \mathrm{O})$, numerical percentage $(\% \mathrm{~N})$, weight percentage $(\% \mathrm{~W})$ and percentage of the index of relative importance (\%IRI) obtained in total stomach contents of anchovies, sardines and sprats.

\begin{tabular}{|c|c|c|c|c|c|c|c|c|c|c|c|c|c|}
\hline & \multicolumn{4}{|c|}{ E. encrasicolus } & \multicolumn{4}{|c|}{ S. pilchardus } & \multicolumn{4}{|c|}{ S. sprattus } \\
\hline & & $\% \mathrm{O}$ & $\% \mathrm{~N}$ & $\% \mathrm{~W}$ & $\%$ IRI & $\% \mathrm{O}$ & $\% \mathrm{~N}$ & $\% \mathrm{~W}$ & $\%$ IRI & $\% \mathrm{O}$ & $\% \mathrm{~N}$ & $\% \mathrm{~W}$ & $\%$ IRI \\
\hline \multicolumn{14}{|l|}{ Protists } \\
\hline Diatoms & Diatoms & 9.62 & 9.21 & 9.58 & 2.31 & 10.17 & 5.25 & 8.21 & 2.01 & 7.83 & 1.07 & 2.89 & 0.36 \\
\hline \multirow[t]{2}{*}{ Dinoflagellates } & Peridinidae & & & & & 3.39 & 0.14 & 0.22 & 0.02 & & & & \\
\hline & Ceratium & & & & & 0.85 & 0.02 & 0.03 & $<0.01$ & & & & \\
\hline $\begin{array}{l}\text { Foraminifera } \\
\text { Crustaceans }\end{array}$ & Foraminifera & 2.88 & 0.05 & 0.13 & $<0.01$ & & & & & 0.87 & $<0.01$ & 0.01 & $<0.01$ \\
\hline \multirow[t]{21}{*}{ Copepods } & Calanus & 3.85 & 0.35 & 0.64 & 0.05 & & & & & & & & \\
\hline & Acartia & 19.23 & 2.66 & 8.70 & 2.79 & 11.02 & 3.24 & 7.58 & 1.75 & 21.74 & 2.17 & 8.96 & 2.84 \\
\hline & Clauso/Paracalanus & 28.85 & 4.93 & 2.30 & 2.66 & 36.44 & 6.35 & 4.59 & 5.85 & 60.87 & 17.89 & 14.90 & 23.41 \\
\hline & Microsetella & 74.04 & 25.18 & 8.76 & 32.06 & 62.71 & 22.17 & 8.98 & 28.63 & 56.52 & 13.30 & 1.90 & 10.08 \\
\hline & Oncaea & 66.35 & 20.04 & 9.79 & 25.25 & 61.02 & 15.70 & 10.80 & 23.70 & 56.52 & 9.12 & 4.09 & 8.76 \\
\hline & Corycaeidae & 43.27 & 4.31 & 25.79 & 16.62 & 40.68 & 7.63 & 26.35 & 20.25 & 47.83 & 7.36 & 26.58 & 19.04 \\
\hline & Euterpina acutifrons & 36.54 & 2.08 & 0.34 & 1.13 & 32.20 & 8.17 & 3.97 & 5.73 & 52.17 & 17.20 & 6.68 & 14.61 \\
\hline & Macrosetella & 0.96 & $<0.01$ & $<0.01$ & $<0.01$ & 0.85 & 0.01 & $<0.01$ & $<0.01$ & & & & \\
\hline & Sapphirina & & & & & 0.85 & 0.34 & 0.42 & $<0.01$ & & & & \\
\hline & Pleuromamma & 3.85 & 0.20 & 0.31 & 0.03 & 2.54 & 0.11 & 0.03 & $<0.01$ & 0.87 & 0.03 & $<0.01$ & $<0.01$ \\
\hline & Centropages typicus & 21.15 & 3.54 & 5.28 & 2.38 & 11.02 & 1.34 & 1.37 & 0.44 & 22.61 & 1.44 & 2.72 & 1.10 \\
\hline & Centropages hamatus & & & & & 0.85 & 0.02 & 0.03 & $<0.01$ & 1.74 & 0.02 & 0.02 & $<0.01$ \\
\hline & Candacia & 10.58 & 0.89 & 3.34 & 0.57 & 2.54 & 0.11 & 0.93 & 0.04 & 4.35 & 0.36 & 1.34 & 0.09 \\
\hline & Oithona & 5.77 & 0.11 & 0.02 & $<0.01$ & 3.39 & 0.17 & 0.04 & 0.01 & 8.70 & 0.29 & 0.09 & 0.04 \\
\hline & Temora & 0.96 & 0.02 & 0.02 & $<0.01$ & & & & & 6.96 & 0.74 & 0.40 & 0.09 \\
\hline & Euchaeta & & & & & & & & & 0.87 & 0.03 & 0.09 & $<0.01$ \\
\hline & Lucicutia & & & & & & & & & 1.74 & 0.02 & 0.03 & $<0.01$ \\
\hline & Clytemnestra & 1.92 & 0.07 & $<0.01$ & $<0.01$ & 2.54 & 0.28 & 0.09 & 0.01 & & & & \\
\hline & Pareuchaeta & & & & & & & & & 0.87 & 0.01 & $<0.01$ & $<0.01$ \\
\hline & Other harpacticoids & & & & & 2.54 & 0.02 & $<0.01$ & $<0.01$ & & & & \\
\hline & Other copepods & 32.69 & 15.02 & 9.86 & 10.37 & 22.88 & 10.07 & 6.81 & 5.66 & 43.48 & 17.67 & 16.09 & 17.22 \\
\hline \multirow[t]{3}{*}{ Cladocerans } & Evadne & 5.77 & 0.17 & 0.01 & 0.01 & 7.63 & 0.85 & 0.46 & 0.15 & 3.48 & 0.07 & 0.08 & $<0.01$ \\
\hline & Podon & 6.73 & 0.15 & 0.03 & 0.02 & 3.39 & 0.15 & 0.11 & 0.01 & 0.87 & 0.06 & 0.05 & $<0.01$ \\
\hline & Other cladocerans & & & & & & & & & 4.35 & 0.25 & 0.03 & 0.01 \\
\hline Ostracods & Ostracods & 22.12 & 1.25 & 1.88 & 0.88 & 11.02 & 0.97 & 1.37 & 0.38 & 13.04 & 0.88 & 0.87 & 0.27 \\
\hline Mysids & Paramysis & 0.96 & 0.27 & 0.24 & $<0.01$ & 10.17 & 7.97 & 8.71 & 2.49 & & & & \\
\hline \multirow[t]{3}{*}{ Amphipods } & Phronima & 1.92 & 0.16 & 0.88 & 0.03 & & & & & & & & \\
\hline & Eusirus or Synopia & 0.96 & 0.11 & 0.21 & $<0.01$ & & & & & & & & \\
\hline & Other amphipods & 0.96 & $<0.01$ & 0.02 & $<0.01$ & & & & & & & & \\
\hline \multicolumn{14}{|l|}{ Chaetognaths } \\
\hline $\begin{array}{l}\text { Chaetognaths } \\
\text { Molluses }\end{array}$ & \multicolumn{12}{|c|}{ Molluses } & $<0.01$ \\
\hline Pteropods & Limacina & 2.88 & 0.07 & $<0.01$ & $<0.01$ & & & & & & & & \\
\hline \multicolumn{14}{|c|}{ Appendicularians } \\
\hline \multicolumn{13}{|l|}{ Cnidarians } & \\
\hline $\begin{array}{l}\text { Siphonophores } \\
\text { Larvae }\end{array}$ & Calycophorae & 1.92 & 0.03 & $<0.01$ & $<0.01$ & & & & & 0.87 & 0.43 & 0.03 & $<0.01$ \\
\hline Crustaceans & Copepodits & & & & & 2.54 & 0.19 & 0.11 & 0.01 & 4.35 & 0.55 & 0.18 & 0.04 \\
\hline & Nauplii & 0.96 & 0.02 & $<0.01$ & $<0.01$ & 5.08 & 0.04 & $<0.01$ & $<0.01$ & 5.22 & 0.05 & $<0.01$ & $<0.01$ \\
\hline & Cirripedia nauplii & 0.96 & $<0.01$ & $<0.01$ & $<0.01$ & 2.54 & 0.12 & $<0.01$ & $<0.01$ & & & & \\
\hline & Cirripedia cypris & & & & & & & & & 0.87 & 0.01 & $<0.01$ & $<0.01$ \\
\hline & Protozoea & 0.96 & $<0.01$ & 0.05 & $<0.01$ & & & & & & & & \\
\hline & Metazoea & 0.96 & 0.01 & 0.02 & $<0.01$ & & & & & 5.22 & 0.23 & 0.42 & 0.04 \\
\hline & Brachyoura & 1.92 & 0.14 & 0.10 & $<0.01$ & 0.85 & $<0.01$ & $<0.01$ & $<0.01$ & 1.74 & 0.08 & 0.13 & $<0.01$ \\
\hline & Decapods & 1.92 & 0.16 & 0.19 & $<0.01$ & & & & & 7.83 & 5.69 & 6.62 & 1.13 \\
\hline & Zoea & 7.69 & 1.05 & 1.97 & 0.30 & 3.39 & 0.07 & 0.68 & 0.04 & 7.83 & 0.16 & 1.21 & 0.13 \\
\hline & Trachelifer & 0.96 & 0.06 & 0.37 & $<0.01$ & & & & & & & & \\
\hline & Euphausiaceans & 7.69 & 2.84 & 3.90 & 0.66 & & & & & 1.74 & 0.95 & 1.06 & 0.04 \\
\hline Molluscs & Gasteropods & 10.58 & 1.79 & 1.65 & 0.46 & 1.69 & 0.11 & $<0.01$ & $<0.01$ & 3.48 & 0.21 & 0.06 & 0.01 \\
\hline & Bivalves & 24.04 & 1.59 & 1.00 & 0.79 & 8.47 & 1.03 & 0.95 & 0.25 & 14.78 & 0.80 & 1.76 & 0.44 \\
\hline Echinoderms & Ophiuroids & 2.88 & 0.03 & $<0.01$ & $<0.01$ & & & & & & & & \\
\hline Teleosts & Teleosts & 0.96 & 0.07 & 0.92 & 0.01 & & & & & & & & \\
\hline Eggs & & & & & & & & & & & & & \\
\hline Eggs & Eggs & 2.88 & 0.12 & 0.02 & $<0.01$ & 18.64 & 2.58 & 0.70 & 0.89 & 6.96 & 0.43 & 0.03 & 0.04 \\
\hline & Anchovy eggs & 16.35 & 1.08 & 1.67 & 0.57 & 10.17 & 4.79 & 6.43 & 1.67 & 14.78 & 0.35 & 0.66 & 0.18 \\
\hline
\end{tabular}


Table A.3. Effect of body length, depth and region of sampling on a) $\delta^{15} \mathrm{~N}$, b) $\delta^{13} \mathrm{C}$, c) $\mathrm{C} / \mathrm{N}$ in anchovies, sardines and sprats. Bold results are significant. The body length covariate was not included in the model if its effect was not significant ( $\mathrm{NC}=$ not computed).

a)

\begin{tabular}{|c|c|c|c|c|}
\hline & 2011 & 2012 & \multicolumn{2}{|c|}{2011 and 2012} \\
\hline Species & E. encrasicolus & E. encrasicolus & S.pilchardus & S. sprattus \\
\hline \multirow[t]{2}{*}{ Length } & $\mathrm{NC}$ & $\mathrm{NC}$ & $F_{1,94}=7.495$ & $F_{1,109}=4.725$ \\
\hline & & & $P=0.007$ & $\mathrm{P}=\mathbf{0 . 0 3 2}$ \\
\hline \multirow[t]{2}{*}{ Depth } & $\mathrm{F}_{1,56}=2.094$ & $F_{1,30}=16.890$ & $\mathrm{~F}_{1,94}=0.060$ & $\mathrm{~F}_{1,109}=0.741$ \\
\hline & $\mathrm{P}=0.154$ & $\mathrm{P}<0.001$ & $\mathrm{P}=0.806$ & $\mathrm{P}=0.391$ \\
\hline \multirow[t]{2}{*}{ Zone } & $F_{2,56}=4.165$ & $\mathrm{~F}_{2,30}=1.258$ & $\mathrm{~F}_{2,94}=0.971$ & $\mathrm{~F}_{2,109}=0.395$ \\
\hline & $P=0.021$ & $\mathrm{P}=0.299$ & $\mathrm{P}=0.382$ & $\mathrm{P}=0.675$ \\
\hline \multirow[t]{2}{*}{ Depth*Zone } & $\mathrm{F}_{2.56}=1.203$ & $F_{230}=3.630$ & $\mathrm{~F}_{294}=0.345$ & $\mathrm{~F}_{2,109}=0.826$ \\
\hline & $\mathrm{P}=0.308$ & $P=0.039$ & $\mathrm{P}=0.709$ & $P=0.440$ \\
\hline
\end{tabular}

b)

2011

2012

\begin{tabular}{|c|c|c|c|c|c|c|}
\hline Species & E. encrasicolus & S. pilchardus & S. sprattus & E. encrasicolus & S. pilchardus & S. sprattus \\
\hline Length & $\begin{array}{l}F_{1,55}=20.274 \\
P<0.001\end{array}$ & $\begin{array}{l}F_{1,52}=13.936 \\
P<0.001\end{array}$ & $\begin{array}{l}F_{1,59}=6.253 \\
P=0.015\end{array}$ & $\mathrm{NC}$ & $\mathrm{NC}$ & $\begin{array}{l}F_{1,43}=4.083 \\
P=0.050\end{array}$ \\
\hline Depth & $\begin{array}{l}\mathrm{F}_{1,55}=0.026 \\
\mathrm{P}=0.873\end{array}$ & $\begin{array}{l}\mathrm{F}_{1,52}=0.404 \\
\mathrm{P}=0.528\end{array}$ & $\begin{array}{l}\mathrm{F}_{1,59}=0.160 \\
\mathrm{P}=0.691\end{array}$ & $\begin{array}{l}\mathrm{F}_{1,30}=0.478 \\
\mathrm{P}=0.495\end{array}$ & $\begin{array}{l}\mathrm{F}_{1,36}=0.309 \\
\mathrm{P}=0.582\end{array}$ & $\begin{array}{l}\mathrm{F}_{1,43}=0.008 \\
\mathrm{P}=0.929\end{array}$ \\
\hline Zone & $\begin{array}{l}F_{2,55}=4.998 \\
P=0.010\end{array}$ & $\begin{array}{l}\mathrm{F}_{2,52}=1.531 \\
\mathrm{P}=0.226\end{array}$ & $\begin{array}{l}\mathrm{F}_{2,59}=1.850 \\
\mathrm{P}=0.166\end{array}$ & $\begin{array}{l}\mathrm{F}_{2,30}=1.761 \\
\mathrm{P}=0.189\end{array}$ & $\begin{array}{l}\mathrm{F}_{2,36}=1.183 \\
\mathrm{P}=0.318\end{array}$ & $\begin{array}{l}\mathrm{F}_{2,43}=2.090 \\
\mathrm{P}=0.136\end{array}$ \\
\hline Depth*Zone & $\begin{array}{l}F_{2,55}=6.296 \\
P=0.003\end{array}$ & $\begin{array}{l}\mathrm{F}_{2,52}=2.433 \\
\mathrm{P}=0.098\end{array}$ & $\begin{array}{l}\mathrm{F}_{2,59}=0.016 \\
\mathrm{P}=0.984\end{array}$ & $\begin{array}{l}\mathrm{F}_{2,30}=1.588 \\
\mathrm{P}=0.221\end{array}$ & $\begin{array}{l}\mathrm{F}_{2,36}=0.135 \\
\mathrm{P}=0.874\end{array}$ & $\begin{array}{l}\mathrm{F}_{2,43}=3.057 \\
\mathrm{P}=0.057\end{array}$ \\
\hline
\end{tabular}

c)

\begin{tabular}{|c|c|c|c|c|}
\hline & 2011 & 2012 & \multicolumn{2}{|c|}{2011 and 2012} \\
\hline Species & S. sprattus & S. sprattus & E. encrasicolus & S. pilchardus \\
\hline \multirow[t]{2}{*}{ Length } & $F_{1,59}=33.903$ & $\mathrm{~F}_{1,43}=10.856$ & $\mathrm{NC}$ & $\mathrm{NC}$ \\
\hline & $P<0.001$ & $P=0.002$ & & \\
\hline \multirow[t]{2}{*}{ Depth } & $\mathrm{F}_{1,59}=0.573$ & $\mathrm{~F}_{1,43}=0.002$ & $\mathrm{~F}_{1,92}=3.027$ & $\mathrm{~F}_{1,95}=0.012$ \\
\hline & $\mathrm{P}=0.452$ & $\mathrm{P}=0.966$ & $\mathrm{P}=0.085$ & $\mathrm{P}=0.913$ \\
\hline \multirow[t]{2}{*}{ Region } & $\mathrm{F}_{2,59}=0.646$ & $\mathrm{~F}_{2,43}=1.279$ & $\mathrm{~F}_{2,92}=1.296$ & $\mathrm{~F}_{2.95}=0.054$ \\
\hline & $\mathrm{P}=0.528$ & $\mathrm{P}=0.289$ & $\mathrm{P}=0.279$ & $\mathrm{P}=0.948$ \\
\hline \multirow[t]{2}{*}{ Depth*Region } & $\mathrm{F}_{2,59}=1.333$ & $\mathrm{~F}_{2,43}=2.027$ & $F_{2,92}=5.709$ & $\mathrm{~F}_{2,95}=2.618$ \\
\hline & $\mathrm{P}=0.271$ & $\mathrm{P}=0.144$ & $P=0.005$ & $\mathrm{P}=0.078$ \\
\hline
\end{tabular}


Table A.4. Diet overlap (\%T) between length class $(\mathrm{cm})$ of anchovies, sardines and sprats using Schoener's formula (1970) on \%IRI (upper diagonal) and \%W (lower diagonal). Bold results are significant $(\% \mathrm{~T} \geq 60)$.

\begin{tabular}{|c|c|c|c|c|c|c|c|c|}
\hline & \multicolumn{3}{|c|}{ E. encrasicolus } & \multicolumn{2}{|c|}{ S. pilchardus } & $\begin{array}{r}S . s p \\
{[7-8[}\end{array}$ & $\begin{array}{l}\text { rattus } \\
{[8-11[}\end{array}$ \\
\hline \multirow{3}{*}{ E. encrasicolus } & {$[8-10[$} & - & 69.28 & 55.38 & 14.00 & 68.47 & 57.90 & 53.44 \\
\hline & [10-12[ & 68.46 & - & 50.13 & 4.93 & 81.34 & 33.47 & 46.11 \\
\hline & [12-13[ & 52.21 & 53.55 & - & 14.21 & 54.64 & 39.19 & 60.22 \\
\hline \multirow{2}{*}{ S. pilchardus } & {$[3-8[$} & 19.19 & 9.03 & 12.48 & - & 3.96 & 13.99 & 14.04 \\
\hline & {$[8-15[$} & 70.06 & 74.44 & 50.75 & 8.12 & - & 37.62 & 58.24 \\
\hline \multirow{2}{*}{ S. sprattus } & {$[7-8[$} & 60.49 & 38.24 & 31.80 & 20.85 & 44.33 & - & 52.19 \\
\hline & {$[8-11[$} & 63.84 & 57.13 & 52.50 & 16.06 & 66.49 & 53.42 & - \\
\hline
\end{tabular}

\section{References}

Ara, K., 2001. Length-weight relationships and chemical content of the planktonic copepods in the Cananéia Lagoon estuarine system, São Paulo, Brazil. Plankton Biology and Ecology 48, 121-127.

Borme, D., Tirelli, V., Brandt, S.B., Fonda Umani, S., Arneri, E., 2009. Diet of Engraulis encrasicolus in the northern Adriatic Sea (Mediterranean): ontogenetic changes and feeding selectivity. Marine Ecology Progress Series 392, 193-209.

Delpy, F., 2013. Écologie du cténophore Mnemiopsis leidy (Agassiz, 1865) dans l'étang de Berre : Étude des facteurs contrôlant sa population et de son impact potentiel sur l'écosystème planctonique. PhD thesis, Aix-Marseille University. 263 pp.

Dumont, H.J., Van de Velde, I., Dumont, S., 1975. The dry weight estimate of biomass in a selection of cladocera, copepoda and rotifera from the plankton, periphyton and benthos of continental waters. Oecologia 19, 75-97.

Lindley, J.A., Robins, D.B., Williams, R., 1999. Dry weight carbon and nitrogen content of some euphausiids from the north Atlantic Ocean and the Celtic Sea. Journal of Plankton Research 21, 2053-2066.

Mauchline, J., 1998. The Biology of Calanoid Copepods. Academic Press, San Diego. 710 pp.

Pitois, S.G., Fox, C.J., 2006. Long-term changes in zooplankton biomass concentration and mean size over the Northwestern European shelf inferred from Continuous Plankton Recorder data. ICES Journal of Marine Science 63, 785-798.

Satapoomin, S., 1999. Carbon content of some common tropical Andaman Sea copepods. Journal of Plankton Research 21, 2117-2123.

Schoener, T.W., 1970. Non-synchronous spatial overlap of lizards in patchy habits. Ecology 51, 408-418.

Uye, S., 1982. Length-weight relationships in important zooplankton from the Inland Sea of Japan. Journal of the Oceanographical Society of Japan 38, 149-158. 
